\title{
THE ERDEMOVIC SENTENCING JUDGEMENT: A QUESTIONABLE MILESTONE FOR THE INTERNATIONAL CRIMINAL TRIBUNAL FOR THE FORMER YUgOSLAVIA
}

\author{
Sienho Yee*
}

On November 29, 1996, Trial Chamber I of the International Criminal Tribunal for the Former Yugoslavia (ICTY) handed down its first sentence: ten years of imprisonment for a crime against humanity, to which Drazen Erdemovic was said to have pleaded guilty (the Sentencing Judgement). ${ }^{1}$ Erdemovic is the first person sentenced by the ICTY and the first sentenced by an international war crimes tribunal since the Nuremberg and Tokyo trials after World War II; as a result, the Sentencing Judgement is a milestone for the ICTY.

Milestone though it may be, I respectfully submit that the Sentencing Judgement is a questionable one. The process leading to the sentencing,

* Member of the New York Bar. J.D., 1993, Columbia Law School. Opinions and errors are personal to the author and shall not be attributed to any organization. The author is not professionally involved in the Erdemovic case discussed herein. This Essay was completed when Erdemovic's appeal was pending before the Appeals Chamber and was submitted to that Chamber and the parties on May 22, 1997. Subsequent developments in the case are not discussed herein. For various assistance, the author is indebted to Ms. Ingrid Kost and her colleagues at the Peace Palace Library in The Hague, to several friends, especially Andreas Paulus who was so generous to read and comment on an earlier draft and to the editors of the Georgia Journal of International and Comparative Law. The author is also grateful to Nosiam Elleafar for giving him a good illustration of fair justice. Comments may be sent to the author at: sienho@msn.com.

${ }^{1}$ Sentencing Judgement, Prosecutor v. Erdemovic, Case No. IT-96-22-T (ICTY, Trial Ch. I, Nov. 29, 1996) [hereinafter Sentencing Judgement]. The British spelling of "judgement" is used in the phrase "Sentencing Judgement" because it is used in the ICTY documents. The Statute of the ICTY was originally an annex to the Report of the Secretary-General, U.N. Doc. S/25704 (1993), and will be referred to as "ICTY Statute" or the "Statute." The Rules of Procedure and Evidence of the ICTY, U.N. Doc. IT/32/Rev. 9, will be referred to as "ICTY Rules." 
from the guilty plea procedure to the Sentencing Judgement's treatment of substantive law regarding the defense of duress and evidence, leaves much to be desired. This essay attempts to detail some of these defects and to make suggestions for remedying them. ${ }^{2}$

Part I describes the proceedings that led to Erdemovic's sentencing in order to provide a picture of what happened. Part II argues that the Trial Chamber's handling of the guilty plea is regrettably defective and deprived Erdemovic of procedural rights. These defects rendered invalid Erdemovic's plea of guilty. The Statute of the ICTY (ICTY Statute or the Statute) and the Rules of Procedure and Evidence of the ICTY (the Rules or Rule) contain only vague and general rules governing the guilty plea procedure which are insufficient. This Part argues that since the Statute and the Rules import the guilty plea procedure from common law, they should be interpreted as having also imported, together with that procedure, the common law safeguards associated with it. The ICTY should thus adopt these safeguards to give concrete content and effect to the vague and general requirements under the Statute and the Rules.

Part III of this paper argues that the Trial Chamber's holding rejecting the defense of obedience to superior orders is valid. Its recognition of the possible availability of duress as a defense to a crime against humanity is correct but its analysis is inadequate. This Part puts forward a new analysis, proposing that duress should not be recognized as a defense to murder as the predicate act for an ordinary war crime falling within the ambit of Article 3 of the ICTY Statute, but should be a defense to murder as the predicate act for a crime against humanity, because the latter requires a specific intent which would be negated when duress is found to exist. Part IV argues that the Trial Chamber's evaluation of evidence is dubious at best. Part V concludes that the Sentencing Judgement should be vacated, and the case should be remanded to give Erdemovic a chance to replead.

\section{BACKGROUND AND PROCEEDINGS}

According to his confession, Erdemovic is a Croat but joined the 10th Sabotage Unit of the Bosnian Serb army. ${ }^{3}$ On July 16, 1995, he and seven

${ }^{2}$ In so doing, I do not intend to provide a comprehensive analysis on the Sentencing Judgement. In particular, its discussion on the determination of the penalty and the enforcement of the sentence is not discussed herein.

${ }^{3}$ Sentencing Judgement, supra note 1 , at para. 79. 
members of the Unit were ordered to leave their base for the Pilica farm to the north-west of Zvornik for a mission. Not until the Unit arrived there were the members informed that they were to kill Muslims. ${ }^{4}$ About 20 buses carrying Bosnian Muslim civilians who had surrendered to the Bosnian police or army then arrived. Erdemovic and the other members of the Unit were ordered to kill these civilians. He immediately refused to do so but was threatened with instant death. He claimed to have seen a superior officer ordering someone to be killed for refusing to obey his orders. Erdemovic believed that he killed about seventy Muslims. ${ }^{5}$ After that, Erdemovic claimed, he was successful in opposing another order to kill five hundred Muslims, with the support of three comrades. Several days later one of his colleagues, Stanko Savanovic, tried to kill him and two of his friends as a retribution for refusing the order. Erdemovic was wounded and was treated in a hospital in Bijeljina and then in Belgrade. After a month of treatment he was released. Traumatized by what happened to him, he contacted a journalist to tell his side of the story. He was then arrested by the Serbian authorities and transferred to Novi Sad to stand trial. ${ }^{6}$

Subsequently, the Prosecutor of the ICTY had Erdemovic transferred to the ICTY and charged him with "a CRIME AGAINST HUMANITY or alternatively a VIOLATION OF THE LAWS OR CUSTOMS OF WAR."” The indictment stated that Erdemovic "committed Count 1: A CRIME AGAINST HUMANITY punishable under Article 5(a) (murder) of the Statute of the Tribunal. . . . Alternatively, Count 2: A VIOLATION OF THE LAWS OR CUSTOMS OF WAR punishable under Article 3 of the Statute of the Tribunal and recognised by Article 3(1)(a) (murder) of the Geneva

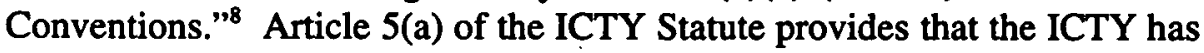
jurisdiction over crimes against humanity. That provision states that the ICTY "shall have the power to prosecute persons responsible for the following crimes when committed in armed conflict, whether international or internal in character, and directed against any civilian population: . . . (a) murder . . . ." Article 3 provides that the ICTY "shall have the power to

${ }^{4} I d$. at paras. 78,80 .

${ }^{5}$ Id. at para. 80.

'Id. at para. 81.

${ }^{7}$ Indictment, Prosecutor v. Erdemovic, Case No. IT-96-22-T (ICTY, May 22, 1996), preamble.

${ }^{8}$ Id. at para. 16.

${ }^{9}$ ICTY Statute, supra note 1 , at art. 5. 
prosecute persons violating the laws or customs of war." 10 This provision contains a list of violations. As expanded by the Appeals Chamber, ${ }^{11}$ this list apparently includes murder as covered under Article 3(1)(a) (murder) of the Geneva Conventions. For the sake of simplicity, "a violation of the laws or customs of war" will be referred to as an "ordinary war crime" throughout this essay.

On May 31, 1996, Erdemovic was brought to appear before the Trial Chamber for the first time, after counsel had been appointed for him. The Trial Chamber asked whether the defense had time to study the indictment, and then had the indictment read in open court. ${ }^{12}$ After explaining that Erdemovic had a right to a trial if he pleaded not guilty, the Trial Chamber asked whether he was prepared to plead and whether he would plead guilty or not guilty. ${ }^{13}$ Erdemovic answered, "I have told my counsel that I plead guilty,"14 without specifying to which count he was pleading guilty. After some slight explanation by the Presiding Judge, Erdemovic told the Chamber that he pleaded guilty "for point one, crime against humanity."15 Afterwards, the prosecution summarized the facts. Erdemovic then stated that he agreed with the prosecutor's statement and had more to add. He then said the following:

Your Honour, I had to do this. If I had refused, I would have been killed together with the victims. When I refused, they told me: "If you are sorry for them, stand up, line up with them and we will kill you too." I am not sorry for myself but for my family my wife and son who then had nine months, and I could not refuse because then they would have killed me. ${ }^{16}$

Subsequent to some further questions, the Trial Chamber "note[d] definitively the plea of guilty by Mr. Erdemovic and ask[ed] that it be placed on the

${ }^{10}$ ICTY Statute, supra note 1 , at art. 3.

1 Decision on the Defence Motion for Interlocutory Appeal on Jurisdiction, The Prosecutor v. Tadic, Case No. IT-94-1-AR72 (ICTY, App. Ch., Oct. 2, 1995), at 48-71. For a discussion on this point, see Theodor Meron, The Continuing Role of Custom in the Formation of International Humanitarian Law, 90 AM. J. INT'L L. 238 (1996).

${ }^{12}$ Transcript of Initial Appearance, Prosecutor v. Erdemovic, Case No. IT-96-22-T (ICTY, Trial Ch. I, May 31, 1996), at 2-6 [hereinafter Transcript].

${ }^{13}$ Id. at 6-7.

14 Id. at 7.

${ }^{15}$ Id.

${ }^{16}$ Id. at 9. 
record of th[e] hearing." ${ }^{17}$ The Trial Chamber then dismissed the second count and prepared for the pre-sentencing proceedings. It also decided to order a psychiatric evaluation of Erdemovic. ${ }^{18}$ The Sentencing Judgement stated that at this hearing it "decided to accept as final Drazen Erdemovic's guilty plea."19

In July 1996, Erdemovic was permitted to testify ${ }^{20}$ during the proceedings pursuant to Rule $61^{21}$ in the case of The Prosecutor v. Karadzic \& Mladic, ${ }^{22}$ who were charged with, among other crimes, genocide and crimes against humanity. On November 19 and 20, 1996, a pre-sentencing hearing was held for the purpose of determining the appropriate sentence for Erdemovic. $^{23}$ On November 29, 1996, the Sentencing Judgement was announced and Erdemovic was sentenced to ten years of imprisonment. On December 18, Erdemovic filed a notice to appeal the judgment of the Trial Chamber. ${ }^{24}$

\section{ThE "GuILTY" PleA}

The first questionable aspect of the Erdemovic sentencing is the procedure through which the guilty plea was accepted. This Part will first describe the guilty plea procedure under the ICTY Statute and Rules and then discuss the potential defects in the Erdemovic case. Finally, this Part argues that these defects alone require that the Sentencing Judgement be vacated and the case be remanded to give Erdemovic a chance to re-plead.

17 Id. at 11.

${ }^{18}$ Id. at $12-13$.

${ }^{19}$ Sentencing Judgement, supra note 1, para. 3.

${ }^{20} \mathrm{Id}$. at para. 6.

${ }^{21}$ Under Rule 61, if after a reasonable time has passed since an indictment was approved and the presence of the accused has not been secured, the Prosecutor may present the evidence in open court and a Trial Chamber may reconfirm the indictment and issue international warrants for the arrest of the accused if there are reasonable grounds for believing the accused committed the crime as charged.

${ }^{22}$ Review of the Indictment pursuant to Rule 61 of the Rules of Procedure and Evidence, Prosecutor v. Karadzic \& Mladic, Nos. IT-95-5-R61, IT-95-18-R61 (ICTY, Trial Ch. I, July 11, 1996).

${ }^{23}$ Sentencing Judgement, supra note 1, at para. 9.

${ }^{24}$ Notice of Appeal by the Defence, Case No. IT-96-22-A (Dec. 23, 1996). 


\section{A. The Guilty Plea Procedure under ICTY Statute and Rules}

The guilty plea procedure is not an indigenous creature in international law. It is a transplant from the common law. In common law countries, a great majority of cases ${ }^{25}$ are disposed of through a plea bargaining process often resulting in the defendant's pleading guilty to a charge lesser than the original one. Administrative efficiency is the common motivating factor for such a system. ${ }^{26}$ The guilty plea procedure ${ }^{27}$ as it exists in common law jurisdictions knows no counterpart in civil law countries where, for one reason or another, efficiency is not perceived to be as compelling. The ICTY is the forum where this procedure was implemented in the international arena for the first time. ${ }^{28}$ The lack of funding and the difficulties in proving an international crime, both more serious than in a national system, make it even more compelling to have the guilty plea procedure. Under such circumstances, having a guilty plea procedure similar to that under common law seems to be unobjectionable.

A simplified mechanism, the guilty plea procedure is strong medicine, and it must be administered with care and proper safeguards to ensure that no

${ }^{25}$ In the United States, guilty pleas account for the disposition of about $95 \%$ of all criminal cases. See Advisory Committee Notes to Fed.R.Crim.P. 11, 1974 amend., reprinted in West Publishing Co., Federal Criminal Code and Rules 44 (1996).

${ }^{26}$ WAYNe R. LAFAVE \& Jerold H. ISRAEl, CRMMINAL PROCEDURe 899 (2d ed. 1992).

27 The Trial Chamber explained the rationale behind this procedure as allowing the accused to adopt his own defense strategy. See Sentencing Judgement, supra note 1, at para. 13.

${ }^{28}$ This procedure is also found in Article 38 of the Draft Statute for an International Criminal Court, produced by the International Law Commission (ILC), in ILC, Report of the International Law Commission on the work of its forty-sixth session, 2 May-22 July 1994, U.N. Doc. A/49/10, at 110 (1994). Comment 5 to Article 38 states:

... the fact that the accused has decided to plead, and has entered a plea of guilty, will not mean a summary end to the trial or an automatic conviction. It will be a matter for the Chamber, subject to the Rules, to decide how to proceed. It must, at a minimum, hear an account from the Prosecutor of the case against the accused and ensure for itself that the guilty plea was freely entered and is reliable. In many cases it may be prudent to hear the whole of the prosecution case; in others, only the key witnesses may need to be called to give evidence, or the material before the Court combined with the confession will themselves be certain proof of guilt. If the accused elects not to be legally represented, it will usually be prudent to ignore the plea and to conduct the proceedings as far as possible in the same way as if they were being vigorously defended.

Id. at 111-12. 
innocent person is punished merely because the procedure has been simplified. The ICTY's Statute and its Rules provide only the most skeletal and vague safeguards. Article 20(3) of the Statute states that after the indictee has been brought to appear before the Tribunal, the Trial Chamber "shall read the indictment, satisfy itself that the rights of the accused are respected, confirm that the accused understands the indictment, and instruct the accused to enter a plea. The Trial Chamber shall then set the date for trial."29 Rule $62,,^{30}$ which governs the initial appearance of the accused, adds that the Chamber shall "call upon the accused to enter a plea of guilty or not guilty on each count; should the accused fail to do so, enter a plea of not guilty on his behalf'; in case of a plea of guilty, the Chamber would instruct the Registrar to set a date for the pre-sentencing hearing rather than a trial. ${ }^{31}$ While Article 20(3) states that the Trial Chamber must satisfy itself that the rights of the accused are respected, it does not specify what those rights relating to a guilty plea are. Rule 62 appears to narrow those rights to simply a right to counsel. ${ }^{32}$ While Article 20(3) and Rule 62(ii) require that the Chamber "confirm" or "satisfy itself," respectively, that the accused understands the indictment, neither prescribes a detailed course of action to ensure that. Further, a judge can be satisfied with more or less, when that is within his wisdom. Although the Rule explicitly requires that the Chamber call upon the accused to make a plea as to each count, it does not provide for a situation where, as in the Erdemovic case, alternative charges have been made.

${ }^{29}$ ICTY Statute, supra note 1, at art. 20(3).

${ }^{30}$ This Rule reads as follows:

Upon his transfer to the seat of the Tribunal, the accused shall be brought before a Trial Chamber without delay, and shall be formally charged. The Trial Chamber shall:

(i) satisfy itself that the right of the accused to counsel is respected;

(ii) read or have the indictment read to the accused in a language he speaks and understands, and satisfy itself that the accused understands the indictment;

(iii) call upon the accused to enter a plea of guilty or not guilty on each count; should the accused fail to do so, enter a plea of not guilty on his behalf;

(iv) in case of a plea of not guilty, instruct the Registrar to set a date for trial;

(v) in case of a plea of guilty, instruct the Registrar to set a date for the presentencing hearing;

(vi) instruct the Registrar to set such other dates as appropriate.

ICTY Rule, supra note 1, at Rule 62.

31 Apparently the Statute contemplates pleas of "not guilty" only, while the Rule provides for the eventuality of a guilty plea.

${ }^{32}$ ICTY Rule, supra note 1, at Rule 62(i). 
To argue for more specific notice of the nature of the crimes, a defendant perhaps could resort to Article 21(4)(a) of the Statute. That provision states that "[i]n the determination of any charge against the accused pursuant to the present Statute, the accused shall be entitled to ... be informed promptly and in detail in a language which he understands of the nature and cause of the charge against him." However, the place where this provision appears normally gives one the impression that it is meant to apply at trial and not at the initial appearance. ${ }^{33}$ Although this need not be the view, it deserves some sympathy. There is no explanation of what "promptly" means anywhere in the Statute or the Rules. However, one can argue that this guarantee applies before trial and, at the latest, at the guilty plea proceeding. ${ }^{34}$ Article 21(4)(a) is a copy ${ }^{35}$ of Article 14(3)(a) of the International Covenant on Civil and Political Rights (ICCPR) ${ }^{36}$ and its interpretation should mirror that given to the language in ICCPR. The Human Rights Committee interpreted the term "promptly" as meaning "as soon as the charge is first made by a competent authority" an investigation a court or an authority of the prosecution decides to take procedural steps against a person suspected of a crime or publicly names him as such." ${ }^{38}$ The ILC adopted this view in 1996 in its Draft Code of Crimes Against the Peace and Security of Mankind (1996 Draft Code). ${ }^{39}$ In a commentary to Article 11 of the 1996 Draft Code, the ILC stated that the "accused must be informed promptly of the charges against him to be able

${ }^{33}$ This position appears to have the support of even Professor M. Cherif Bassiouni. $C f$. M. Cherif Bassiouni \& Peter manikas, The LaW of the international Criminal TRIBUNAL FOR THE FORMER YUGOSLAVIA 955 (1996). The leamed authors so stated the caption of section 12.11 "Article 21: Protection of the Rights of the Accused [During Trial]." (Brackets in original).

${ }^{34}$ Here I note with alarm that counsel for defendant Tadic complained in his opening statement that "The Trial starts today, while only last Friday the Judges told our client, "We do not know which elements are necessary to prove the offences charged.' "Transcript of Proceedings on May 7, 1996, at 36, Prosecutor v. Tadic, No. IT-94-1-T (ICTY, Trial Ch. II).

${ }^{35}$ See Report of the Secretary-General, U.N. Doc. S/25704, para. 107.

${ }^{36}$ International Covenant on Civil and Political Rights, Dec. 16, 1966, art. 14(3)(a), 999 U.N.T.S. 171.

${ }^{37}$ Human Rights Committee, General Comment 13/21, para. 8, reprinted in MANFRED NOWAK, CCPR COMMENTARY 859 (1993).

${ }^{38}$ Id.

${ }^{39}$ ILC, Draft Code of Crimes Against the Peace and Security of Mankind, in Report of the International Law Commission on the work of its forty-eighth session, 6 May-26 July 1996, U.N. Doc. A/51/10, at 9 [hereinafter 1996 Draft Code]. 
to respond thereto at any preliminary proceeding and to have adequate time to prepare his defence." 40 Under this interpretation, "preliminary proceedings," and not just the trial proper, are covered. This appears to be the view of the Trial Chamber. The Presiding Judge stated at the initial appearance proceeding that " $[t]$ his initial hearing is based on the rules and our statutes, specifically Articles 20 and 21 of the Statute of the Tribunal, 21(B) devoted [to] the rights of the accused and [Rule] 62..."41 As is clear, the Judge thought that Article 21 was applicable, but he just skipped Article 21(4)(a), and did not give it any meaning otherwise.

Another problem with resorting to this provision is that we still do not know the meaning of the terms "in detail" and "nature and cause." While the Human Rights Committee stated that the requirements "may be met by stating the charge either orally or in writing, provided that the information indicates both the law and the alleged facts on which it is based,"42 one is still at a loss as to whether a skeletal indictment making references to the statutes on the books, such as the one against Erdemovic, is sufficient for this purpose. This uncertainty is not resolved even if we adopt Manfred Nowak's elaboration that "[n]ature and cause of a criminal charge means not only the exact legal description of the offence but also the facts underlying it."43 We do not know whether the "exact legal description of the offence" requires an delineation of the elements of the offense, both factual and mental, or merely a reproduction of the applicable statutory language. Nor does the ILC's formulation that " $[t]$ he accused must be informed of the nature and cause of the charges in a meaningful way so as to be able to fully comprehend the alleged wrongdoing and to respond to the allegations" 44 add much more. Reasonable minds may differ as to what is "meaningful." Finally, the ICCPR language does not specify how the defendant should be informed. Perhaps serving him a valid indictment may be sufficient.

As we can see, the procedural requirements that the Trial Chamber must comply with in a guilty plea proceeding under the Statute or the Rules can only be characterized as general and vague. On their face, they do not provide any specific or meaningful procedure governing the receiving of a guilty plea.

\footnotetext{
${ }^{40} \mathrm{Id}$. at art. $11 \mathrm{cmt} .13$.

${ }^{41}$ Transcript, supra note 12, at 2.

42 Human Rights Committee, supra note 37.

${ }^{43}$ NowAK, supra note 37 , at 255.

1996 Draft Code, supra note 39, at art. $11 \mathrm{cmt} .13$.
} 


\section{B. Potential Defects in the Erdemovic Case}

As far as the black letters of the Statute and the Rules are concerned, it appears that the Trial Chamber complied with them. Counsel was appointed for the defendant. The Chamber inquired into whether the defendant had had time to study the indictment and to discuss it with his counsel, and whether the facts alleged in the indictment had been presented to him in a language he understood. ${ }^{45}$ Nevertheless, observing the guilty plea proceeding in this case left me with serious doubts as to whether justice has been done. Several things struck me as questionable if not revolting. First, although Erdemovic was confronted with two alternative charges of a crime against humanity or an ordinary war crime, when asked "do you plead guilty or not guilty?", ${ }^{6}$ he simply answered "I have told my counsel that I plead guilty,"47 without specifying guilty to which count. Second, history saw, perhaps for the first time, ${ }^{48}$ a man pleading guilty to a more serious crime rather than a lesser one, when faced with the alternative charges of a crime against humanity or an ordinary war crime, the former being clearly much more serious than the latter. Third, while he pleaded guilty to a crime against humanity, the defendant cried and "struggled to contain his emotion,"49 and then told the Chamber that he had to "do this" or to be killed himself. Finally, the defendant made the guilty plea with counsel by his side.

These happenings, in my opinion, bespoke miscarriage of justice and invalidated the plea. They demonstrate that Erdemovic neither understood the nature of the charges or the meaning of alternative charges, nor did he unequivocally plead guilty. They also suggest that the advice of counsel was suspect. Notwithstanding these surreal happenings, Trial Chamber I of the ICTY, which was expected to carry out exemplary justice on behalf of the international community, believed that it had one guilty plea and accepted it as final.

${ }^{45}$ Transcript, supra note 12 , at 3 .

${ }^{46}$ Id. at 7.

${ }^{47}$ Id.

${ }^{48}$ While I cannot produce materials to confirm this "first" quality of this plea, my friends in the United States, including practitioners and an experienced federal judge, told me that they had never heard of such a plea. This is hardly surprising. That a guilty plea can happen is due largely to the fact that both sides of a case make compromises during a plea bargaining process and most of the time the prosecutor agrees to lower the charge.

${ }^{49}$ Croat Soldier Pleads Guilty to Slayings at Srebrenica, INT'L HERALD TRIB., Jun. 1-2, 1996, at 1, 4. 
One may ask why, although the general requirements of the ICTY Statute and Rules have been complied with on their face, a miscarriage of justice still apparently resulted. I am not at liberty to speculate as to why the judges acted as they did in accepting the guilty plea, but I believe the lack of proper, specific safeguards for the rights of the defendants during a guilty plea proceeding is the culprit. The general requirement under Article 20(3) and Rule 62 that the Trial Chamber must satisfy itself that the accused understands the indictment is not adequate. This provision is susceptible to many interpretations and affords no real guarantee that the defendant will receive meaningful notice of the charges. One interpretation is that under Article 20(3) and Rule 62 the Chamber may rely upon the defendant's statement that he understands the charge. This was exactly what the Trial Chamber did in this case. ${ }^{50}$ This approach smacks of relying upon a drunkard's swearing that he is not drunk, although he can neither talk straight nor walk straight.

In order to be meaningful, the general and vague requirements under the ICTY Statute and Rules must be given concrete content. This the Trial Chamber did not do. Faced with Erdemovic's obvious lack of understanding of the nature of the charges and the possible defenses, the Trial Chamber did nothing to assist him, while at the same time asserting that it "wished to ensure that, starting from the initial appearance, the plea was. made voluntarily and in full cognisance of the nature of the charge and its consequences." 51 The Trial Chamber understood the issue simply as a psychiatric one. Thus, while the Trial Chamber ordered a psychiatric evaluation of Erdemovic to determine whether he "currently suffer[ed] from a psychiatric or neuropsychiatric disorder or from an emotional disturbance which affect[ed] his judgement or his volition," 52 it did not itself conduct, or otherwise obtain, any evaluation of his understanding of the legal nature of the charges. It did not provide a legal description of the charges. It did not explain the different consequences of pleading guilty to a crime against humanity or an ordinary war crime.

One is naturally prompted to inquire into how the common law system, which gave birth to the guilty plea procedure, deals with the problems that

${ }^{50}$ Transcript, supra note 12, at 6 ("According to what you said before, you understood what is contained in this indictment as well as the charges against you, those charges which the Prosecution has made against you.").

${ }^{51}$ Sentencing Judgement, supra note 1 , at para. 11.

52 Id. 
existed in the Erdemovic case. On the level of generality and abstraction, the requirements in common law jurisdictions do not differ dramatically from the language of Article 20(3) and Rule 62(ii), requiring that the Chamber "confirm" or "satisfy itself," respectively, that the accused understands the indictment. Thus, United States law requires that a guilty plea, to be valid, must "represent[] a voluntary and intelligent choice among the alternative courses of action open to the defendant." $\$ 3$ How to measure such understanding and how to achieve that understanding is dramatically different. While the Statute and the Rules are silent on these points, thus leaving them to the wisdom of the Trial Chambers, common law jurisdictions have transformed the generality into concrete steps to ensure that a plea is made voluntarily and intelligently. They have developed an elaborate procedure and specific safeguards either by statute, court rules, or case law, aimed at strengthening the defendant's understanding of the charges and the choices available to him. $^{54}$

In construing the general and vague requirements with respect to the guilty plea proceedings under the ICTY Statute and Rules, the ICTY should adopt the important common law safeguards ${ }^{55}$ to ensure that a guilty plea is made voluntarily and intelligently. While it may be better to effect such an adoption through rule-making by the plenary session of the Judges, a Chamber confronting such issues cannot and should not wait for that event to take place. It is obligated to provide due process and to do justice whenever it decides an issue. Due process and justice require that the common law safeguards be adopted before a guilty plea is accepted, under the auspices of interpreting the Statute and the existing Rules.

I argue for such an adoption not simply because I am a prisoner of my experience as a lawyer first trained in the common law tradition. There are cogent reasons for this position. First, as discussed above, international law, as embodied in the Statute and the Rules, is not clear, containing only vague and general rules on these issues; one must thus seek help from general principles of law in order to give content and effect to the vague and general requirements. Common law jurisdictions appear to be the only place where such general principles can be found. Second, the common law safeguards are minimal guarantees that the common law system, the only system that

\footnotetext{
33 North Carolina v. Alford, 400 U.S. 25, 31 (1970).

${ }^{34}$ Cf. id.

55 For the sake of simplicity, the phrase "common law safeguards" refers to both those safeguards originated from case law and those from statutes in common law jurisdictions.
} 
has experience with the guilty plea procedure, believes to be necessary to ensure that a guilty plea represents a voluntary and intelligent choice made by the defendant. For this reason, one may say that these safeguards cannot be derogated from when the same procedure gets transplanted somewhere else. When international law imports an expedited procedure from the common law system, it is only fair that it should, together with the procedure, adopt those common law safeguards associated with that procedure, unless those safeguards are offensive to international law. Otherwise, international law would give credence to the proverbial saying that a recent convert is more fervent than a veteran believer, and would "outcommon law" common law by making the expedited procedure even more expedited. Without such minimal safeguards, an expedited procedure already vulnerable to abuse in its native environment, once transplanted, can easily fall prey to further abuse. These safeguards are mostly for the benefit of the defendant and can hardly be offensive to international law.

Without providing a comprehensive treatise on the these safeguards, I will here discuss some of them, and explain how they, if implemented, might have made a difference in this case. I will do so primarily in light of the safeguards provided under the federal law of the United States and, to a lesser extent, those provided in the United Kingdom.

1. The Requirement that the Court Inform the Defendant Personally and Determine His Understanding of the Nature of the Charges

Under the United States Federal Rules of Criminal Procedure, the first and most important step that the Court must take before accepting a guilty plea is to "address the defendant personally in open court and inform the defendant of, and determine that the defendant understands . . . the nature of

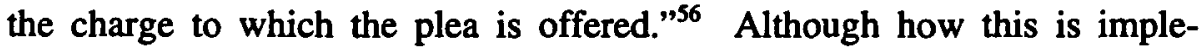
mented may vary from case to case, depending on the complexity of the circumstances and the particular defendant, today the "better practice is for the judge to inform the defendant of the nature and elements of the offense to which the plea is offered, that is, the acts and mental state and attendant circumstances which the prosecution would have to prove in order to establish guilt at trial." 57 While this might not need to be followed strictly in every case, it should be followed in complex cases and with respect to

\footnotetext{
${ }^{56}$ Fed.R.Crim.P. $11(\mathrm{c})(1)$

${ }^{57}$ LAFAVE \& ISRAEL, supra note 26, at 934.
} 
critical elements of the offense, ${ }^{58}$ or when the defendant manifests his misunderstanding or confusion with respect to the nature of the charges. This requirement is to make sure that "the defendant received 'real notice of the true nature of the charge against him, the first and most universally recognized requirement of due process." "59 In sum, the defendant's plea cannot be voluntary "unless the defendant possesses an understanding of the law in relation to the facts"60 and should not be accepted unless he pleads "with appreciation of the essential elements of the offence."

A description of the elements of the crimes takes on greater importance in the context of the ICTY, the first international tribunal charged with adjudicating war crimes and crimes against humanity since the Nuremberg and Tokyo trials. The applicable substantive law relating to these crimes is not crystal clear, and the little that is clear is very complex. This in itself poses a problem as to whether the legality principle of nullum crimen sine lege has been observed. With respect to the term "crime against humanity," there has even been dispute as to its definition as recently as in $1994 .^{62}$ Under such circumstances, a delineation of the elements of the crimes by the Trial Chamber is necessary for the accused to make a voluntary and intelligent guilty plea. Erdemovic was not given a description of the elements of the crimes in this case. Indeed, at no point during the guilty plea proceeding did the Trial Chamber discuss the nature of the charges in any substantive manner. This attitude persisted with tenacity in the Sentencing Judgement where the Trial Chamber stated that it "reaffirms that there is no valid reason for discussing the charge of crime against humanity since Drazen Erdemovic pleaded guilty to this count." ${ }^{13}$ The indictment does not contain any such description; it merely refers to the relevant provisions in the ICTY Statute. Referencing to the laws on the books is seldom considered sufficient in common law jurisdictions and should be considered less so in an international court of law because the applicable law there is more complex.

${ }^{58}$ Id. at 934-35.

59 Smith v. O'Grady, 312 U.S. 329, 334 (1941), as cited in Henderson v. Morgan, 426 U.S. 637, 645 (1976).

${ }^{60}$ McCarthy v. United States, 394 U.S. 459, 466 (1969).

61 11(2) HALSBURY'S LAWS OF ENGLAND 823 (4th ed. 1990).

62 See generally M. Cherif Bassiouni, "Crimes Against Humanity": The Need for a Specialized Convention, 31 ColuM. J. TRANS. L. 457 (1994).

${ }^{63}$ Sentencing Judgement, supra note 1 , at para. 83. 
Moreover, with respect to the definition of "crime against humanity," the ICTY Statute itself is inadequate. As described below, ${ }^{64}$ Article 5 of the Statute borrows the definition of "crime against humanity" from the Nuremberg Charter, but that definition was refined by the International Military Tribunal at Nuremberg. The ILC has now added "when committed in a systematic manner or on a large scale and instigated or directed by a Government or by any organization or group" to the definition in order to provide a more accurate restatement of the current understanding of what constitutes a crime against humanity. ${ }^{65}$ This refinement is not reflected in, but should be incorporated into, Article 5 of the ICTY Statute.

It is obvious that Erdemovic did not understand the nature of the charges. The fact that he initially simply pleaded guilty to two alternative charges without specifying which one and subsequently opted for the more serious charge rather than a lighter one speaks volumes. Erdemovic's misunderstanding is three-fold: first, he did not understand the nature of either charge; second, he did not understand that there were two alternative charges; and third, he apparently believed that they were the same or constituted one crime. After the initial plea, the Presiding Judge explained that "the various acts could either be classified as a crime against humanity or what we call violations of laws or customs of war," what these crimes were. Nor did the Chamber ascertain whether Erdemovic's counsel had specifically explained the differences. ${ }^{67}$ Although the Presiding Judge stated "I suppose you have spoken about this with your attorney?"," Erdemovic gave no answer and the Judge did not press for it. Such statements and questions did nothing to help eliminate the misunderstanding.

${ }^{64}$ See infra notes $163-173$ and accompanying text.

651996 Draft Code, supra note 39, at art. 18.

${ }^{66}$ Transcript, supra note 12, at 7.

${ }^{67}$ Nevertheless, Erdemovic's counsel reported that "With my client, I spent some time, several hours, studying the indictment and studying his rights according to the Statute and Rules of the Tribunal. I think that he had enough time to comprehend what he is charged with by this indictment and to understand his rights on that basis." Id. at 3. One may question whether "several hours" are sufficient for such serious business.

${ }^{68}$ Id. 
2. The Requirement that the Court Inform the Defendant Personally of Possible Affirmative Defenses when Made Aware of Facts that Would Constitute such a Defense

An important aspect of the detailed requirement for apprising a defendant of the nature of the charges is that when a judge is made aware, by whatever means, of facts that would constitute a defense he must personally inform the defendant of the law relating to it. ${ }^{69}$ This requirement is necessary because crimes and defenses can hardly be separated. Not being a lawyer, the accused may not understand such difficult concepts by himself. Where facts indicate lack of understanding with respect to a defense on the part of the accused, the court must explain it to him or her. This requirement is born of concerns for fundamental fairness. With their superior knowledge of law or facts, judges should not accept a guilty plea made by a defendant who is without the benefit of such knowledge. It is revolting to see an accused who has a colorable defense going to jail without a good fight. After all, a guilty plea is not a bargain to be struck at a flee market where the maxim "buyer beware" reigns.

In the Erdemovic case, the Judges were made aware of the possible defenses at the guilty plea proceeding on May 31, 1996, if not from previous reporting by the mass media. The Trial Chamber did not dispute that the defenses are potentially available, and in fact discussed them in the Sentencing Judgement, although it ultimately rejected them. ${ }^{70}$ Under such circumstances, the Judges were obligated to explain the possible defenses to Erdemovic. This the Judges did not do. If given such an explanation, Erdemovic might not have pleaded guilty. When he told the Judges that he "had to do this," he was saying in layman's terms that he was not culpable as a matter of law. If apprised of the possible defenses, he might have claimed that he had a defense in more explicit terms, rather than pleading guilty and then explaining that he was forced to do what he did.

\section{The Requirement that the Court Inform the Defendant Personally of the} Consequences of his Plea

Under the United States Federal Criminal Procedure, the Court must inform the defendant personally of the possible consequences of his plea;

${ }^{69}$ See LAFAVE \& ISRAEI, supra note 26, at 935. See also R. v. Durham Quarter Sessions ex parte Virgo 1 All E.R. 466 (1952).

${ }^{70}$ Sentencing Judgement, supra note 1, paras. 11-21. 
such as maximum possible penalty provided by law, possible restitution to the victim, etc. ${ }^{71}$ Although this rule does not specifically address the consequences of alternative charges, presumably judges and lawyers know that when alternative charges are made, the consequences must be also in the "alternative." This being the case, the court must inform the defendant of all the alternative scenarios under the alternative charges, as part of its duty to inform the accused of the consequences of the plea.

The Trial Chamber did not provide a meaningful explanation on the possible consequences that would result from pleading guilty to either of the alternative charges, although the Trial Chamber attempted to apprise Erdemovic of the consequences in general. The Chamber explained the differences between a trial and a sentencing hearing to determine the penalty, ${ }^{72}$ and reminded Erdemovic that "the crimes that this Tribunal is charged with punishing can be punished by a sentence of life imprisonment."73 The Chamber, however, did not separately explain the consequences (in terms of differences in possible penalties and mitigation) of pleading guilty to the charge of a crime against humanity or alternately an ordinary war crime.

The Chamber's failure to explain the alternative scenarios of the possible consequences substantially contributed to Erdemovic's irrational behavior in pleading guilty to the more serious count of the two alternative charges, if this failure alone had not caused it. While pleading guilty to a lesser charge does not necessarily preclude the prosecution of the more serious count, ${ }^{74}$ a defendant pleading guilty to the lesser charge would have little to lose. On the other hand, he would have nothing to gain by pleading guilty to the more serious charge. Moreover, other means of pleading may be available to him. For example, he may perhaps offer a conditional plea, i.e., pleading guilty to an ordinary war crime on the condition that the charge of a crime against humanity be dismissed.

The differences in the gravity of these two crimes and the resulting penalties are beyond dispute. They were recognized by the Chamber itself

${ }^{11}$ Fed.R.Crim.P. 11(c)(1).

${ }^{2}$ Transcript, supra note 12 , at $6,9$.

${ }^{73}$ Id. at 10 .

74 11(2) HALSBURY'S LAW OF ENGLAND $824 \mathrm{n} .7$ (4th ed. 1990) ("If the counts are alternative, eg robbery and dishonest handling, a plea of guilty to dishonest handling does not preclude a trial for robbery, and, if the accused is convicted of robbery, the plea of guilty on the alternative count of dishonest handling may be allowed to remain on the file marked not to be proceeded with without leave of the court."). 
in its Sentencing Judgement. There, the Chamber emphasized that the extreme gravity of a crime against humanity is such that no aggravating circumstances were necessary for the purpose of sentencing. ${ }^{75}$ The penalty for an ordinary war crimes is normally less severe than for a crime against humanity, all else being equal. Moreover, mitigation may present less of a problem when an accused is convicted of an ordinary war crime than when he is convicted of a crime against humanity. Erdemovic's sentence might have benefited more from mitigation had he pleaded guilty to the charge of an ordinary war crime. Given these differences, the failure to explain the different scenarios of consequences must be considered an error invalidating the guilty plea.

\section{The Requirement that the Court Determines that There Is a Factual} Basis for the Plea before Entering a Judgment of Conviction

In common law countries, the Court must determine the factual basis of the plea. The United States Federal Rules of Criminal Procedure direct that "[n]otwithstanding the acceptance of a plea of guilty, the court should not enter a judgment upon such plea without making such inquiry as shall satisfy it that there is a factual basis for the plea."76 In the United Kingdom, "upon a plea of guilty the prosecution should thereupon state the facts in open court." W7 While this requirement serves many functions, ${ }^{78}$ it is first and foremost designed to protect a defendant who "is in the position of pleading voluntarily with an understanding of the nature of the charge but without realizing that his conduct does not actually fall within the charge,"79 and to provide the court with a "better assessment of [the] defendant's competency and willingness to plead guilty and his understanding of the charges." ${ }^{100}$ This requirement to inquire into the factual basis for the plea has been adopted by the ILC in its commentary to Article 38 of Draft Statute for an International Criminal Court. ${ }^{81}$

75 Sentencing Judgement, supra note 1 , at para. 45.

${ }^{76}$ Fed.R.Crim.P. 11(f).

77 11(2) HALSBURY's LAW OF ENGLAND 823 (4th ed. 1990) (citing Practice Direction, 2 All E.R. 144, (1968)).

${ }^{78}$ For example, it is believed that this results from the fact that the "public has a right to know the circumstances of the commission of an offence." Id.

${ }^{79}$ Advisory Committee Notes to Fed.R.Crim.P. 11(f), 1966 amend., supra note 25, at 42.

${ }^{80}$ LAFAVE \& ISRAEL, supra note 26, at 938.

${ }^{81}$ ILC, supra note 28 , at 111-12. 
In Erdemovic, the Trial Chamber failed to inquire into the factual basis for the mental state of the accused that a crime against humanity requires, although the Chamber did attempt to make certain that victims had died, and that Erdemovic killed them. However, the fact that victims had died, and that the accused actually killed them does not necessarily mean that a crime against humanity has been committed. As explained below, ${ }^{82}$ an important element of the crime is that the accused must have willingly participated in the killing at the instigation or direction of the government or an organized group. This the Chamber did not attempt to ascertain. If it did, the Chamber may have had difficulty in this respect. The little that can be distilled from the accessible documents indicates the absence of the mens rea for the crime against humanity. The facts appeared to show that the accused had no knowledge of the plan to kill the bus loads of victims. Only shortly before the victims arrived was he ordered to kill them. There did not appear to be any evidence of Erdemovic's wilful endorsement of or participation in the plan to kill the victims. In short, there was no evidence that he wilfully followed the instigation or direction of a government or organized group. He was coerced into "committing the crime," if there was a crime.

\section{The Requirement that the Court Not Acrept Any Equivocal Guilty Pleas}

A cardinal rule in common law countries is that the court must not accept an equivocal guilty plea. The accused "is not to be taken to admit an offence unless he pleads guilty to it in unmistakable terms." ${ }^{\text {"33 }}$ An equivocal plea may result when the accused offers his plea in words that amount to raising a defense. One type of situation that causes the accused to do this is when he is vaguely aware that he is not morally at fault, but does not have the legal knowledge of the possible defenses that may be available to him. The accused apparently admits that he actually committed the physical act, but insists that he was not morally at fault, which, in legal terms, amounts to saying that he is not legally guilty. Actual cases vividly demonstrate this scenario. In one case the accused pleaded "Guilty, in self-defence." 84 In another case the accused pleaded guilty to receiving stolen horses, but at the same time handed a statement to the court stating that "I am guilty of taking

\footnotetext{
${ }^{82}$ See infra notes 163-173 and accompanying text.

83 11(2) HALSBURY'S LAW OF ENGLAND 823 (4th ed. 1990).

${ }^{84}$ R. v. Emery, 29 Crim. App. 47 (1943).
} 
the horses not knowing them to be stolen." 85 In yet another case, the accused pleaded guilty to stealing a motor bicycle. When asked whether he had anything to say, he explained, "It was a mistake, I thought it was my mate's cycle. My mate said, 'Take it home.' My mate's bike is identical." ${ }^{\text {"86 }}$ These accused presented their best defense in layman's words. Without more, the courts have considered such pleas to be pleas of "not guilty." Under such circumstances, the judge should explain the law and ask the defendant to plead anew. If the plea continues to be equivocal, a "not guilty" plea must be entered. If the judge does not make further inquiry into an equivocal plea, its validity may be challenged.

There are surprising similarities between these pleas and Erdemovic's plea. Although Erdemovic pleaded guilty, he stated that he had to "do this" to spare his life and those of his wife and child. Indeed, the Trial Chamber in its Sentencing Judgement recognized that the accused's plea may be "ambiguous or equivocal,"87 and that he "argued both an obligation to obey the orders of his military superior and physical and moral duress stemming from his fear for his own life and that of his wife and child." ${ }^{88}$ Once this argument has been made, the proper course of action for the Chamber should be to explain the law and ask the accused to plead again to ensure that the plea was a willing and intelligent one, or alternately, to enter a plea of not guilty. The Trial Chamber did neither. It simply wrote a long essay in the Sentencing Judgement on how weak the defenses were, and concluded that "[o]n the basis of the case-by-case approach and in light of all the elements before it, the Trial Chamber is of the view that proof of the specific circumstances which would fully exonerate the accused of his responsibility has not been provided." 89 It is amazing that the Trial Chamber came to this conclusion. It should have asked whether Erdemovic was to bear the burden of proof and, if so, whether he was given a chance to present his case.

As argued below, Erdemovic should bear only a limited burden to provide some evidence to raise the issue, and then the prosecution should bear the burden of persuasion to disprove duress. ${ }^{90}$ In any event, he was not given a chance to produce proof. He was asked to make a plea, and then there

\footnotetext{
${ }^{85}$ R. v. Ingleson, 1 K.B. 512 (1915).

${ }^{86}$ R. v. Durham Quarter Sessions, ex parte Virgo, 1 All. E.R. 466 (1952).

${ }^{87}$ Sentencing Judgement, supra note 1 , at para. 14.

${ }^{88}$ Id.

${ }^{89}$ Id. at para. 20.

${ }^{\infty}$ See infra Part IV.A.
} 
were status conferences and a pre-sentencing hearing. ${ }^{91}$ No trial was held. Thus, the Trial Chamber was conducting a trial on paper without any input from the defense, thus short-circuiting the defendant's right to trial. Under no law may a trial court do this. Once it recognized that a defense was raised, the Trial Chamber should have entered a "not guilty" plea and proceeded to conduct a trial. The Chamber did not do so; on the contrary, it proceeded to have Erdemovic's psychological status examined and to conduct a pre-sentencing hearing, ${ }^{92}$ and then settled the matter with respect to the defenses on paper.

Another type of situation that causes the accused to make an equivocal plea is when the accused believes he is not guilty, but pleads guilty in order to spare him from being tried on a more serious crime, thus risking a harsher punishment, such as the death penalty. In North Carolina v. Alford, ${ }^{93}$ after the defendant pleaded guilty to second degree murder and the prosecution presented an abbreviated version of the factual basis for the crime. The defendant took the stand and denied that he committed the crime, but stated that he decided to plead guilty to second degree murder to avoid being tried for first degree murder as he was charged and, thus, the possible punishment of death penalty. He also stated that his counsel explained to him the differences between first- and second-degree murder. At that point, the judge asked, in light of his denial of guilt, whether he still desired to plead guilty. The accused reaffirmed his desire. Having heard further testimony indicating his guilt and having reviewed his long criminal record, the judge then sentenced the accused to 30 years of imprisonment, the maximum penalty. ${ }^{94}$ The U.S. Supreme Court affirmed the decision of the trial court. In its view, the defendant intelligently concluded that his interests required entry of a guilty plea when confronted with the choice between a trial for first-degree murder with possible death penalty and a plea of guilty to second-degree murder with a maximum penalty of 30 years of imprisonment. In view of the strong factual basis for the plea and Alford's clearly expressed desire to enter a guilty plea despite his professed belief in his innocence, the Supreme Court held that the trial judge committed no constitutional error in accepting it. ${ }^{95}$

\footnotetext{
${ }^{91}$ Sentencing Judgement, supra note 1, at paras. 3-9.

92 Id.

${ }^{93}$ North Carolina v. Alford, 400 U.S. 25 (1970).

94 Id. at 27-29.

${ }^{95}$ Id. at 37-38.
} 
With respect to the issue of possible defenses, Alford is inapposite to the Erdemovic case since there was no apparent affirmative defense raised in Alford. Alford just asserted that he did not commit the crime. With respect to the choice of charges to plead guilty to, Alford is the opposite of Erdemovic. Unlike Alford who pleaded guilty to a lesser crime, Erdemovic "pleaded" guilty to a more serious one. While Alford obviously made an intelligent choice in order to avoid the death penalty, one is hard pressed for a logical explanation for Erdemovic's "choice." Finally, the Trial Chamber's decision to permit Erdemovic to adopt his own defense strategy of pleading guilty ${ }^{96}$ has some similarity to that of the Supreme Court in Alford. However, even if the Trial Chamber's emphasis is correct with respect to pleading guilty to some charge, it cannot explain why that charge has to be "a crime against humanity" and not "an ordinary war crime." Moreover, the emphasis on the choice of defense strategy is based on the fact that the defendant understands the nature of the charge and the choice, and his "clearly expressed" choice, none of which can be found in Erdemovic. In Alford, the trial judge asked the accused whether he still desired to plead guilty in light of his denial of guilt, the Trial Chamber in Erdemovic did not do that after Erdemovic's emotional statement that he had to do the horrid deeds. Rather, the Presiding Judge asked Erdemovic to "[t]ry to get a hold of yourself." Humane though this was, it did not help Erdemovic make a willing and intelligent plea.

\section{The Requirement that the Assistance of Counsel Must be Effective}

In common law countries, the accused's right to counsel applies to the guilty plea proceeding, a critical stage of the criminal process. This right encompasses effective assistance of counsel, not just assistance of counsel. ${ }^{98}$ The counsel's actions and conduct must fall within the range of competence demanded of attorneys in criminal cases.9

While the Statute ${ }^{100}$ and Rules ${ }^{101}$ of the ICTY clearly provide for the accused's right to assistance of counsel, they do not define the competence

\footnotetext{
\% Sentencing Judgement, supra note 1, at para. 13.

${ }^{97}$ Transcript, supra note 12 , at 9.

98 LAFAVE \& ISRAEL, supra note 26, at 922-26.

${ }^{99}$ Id. at 923 (citing McMann v. Richardson, 397 U.S. 806 (1970)).

${ }^{100}$ ICTY Statute, supra note 1, at arts. 18(3), 21(4)(b), (d).

${ }^{101}$ ICTY Rules, supra note 1, at Rules 44-46.
} 
of counsel in relation to criminal cases. Under Rule 44, "A counsel shall be considered qualified to represent a suspect or accused if he satisfies the Registrar that he is admitted to the practice of law in a State, or is a University professor of law."102 This Rule does not help to provide effective counsel. It would be little comfort to an accused to be represented by even a prominent practitioner or professor of law who specializes in trusts and estates, for example. The ICTY should require some prior exposure to, if not specialty in, criminal matters.

Another aspect of the competence of counsel is whether a counsel should at least have some knowledge of international law, given the international character of the ICTY. Neither the Statute nor the Rules specifically address this requirement, but Rule 45 contains a language requirement that may be deemed a proxy for it. When counsel for Erdemovic was appointed, Rule $45(A)^{103}$ required that he or she speak one of the working languages of the ICTY, that is, either English or French. This is a salutary rule not simply because the working languages of the ICTY are English and French, but also because, more importantly, most of the materials on international law are traditionally written in English or French. The very job of the ICTY is to adjudicate international crimes. If the counsel does not have much experience in international law, his proficiency in either English or French would at least give him the tool to do research. If one does not speak or read English or French, he would have difficulty accessing international legal materials and may be, presumably, incompetent to practice international criminal law, with great respect to many prominent international law scholars who write in other languages. It is unfortunate that this language requirement has now been relaxed to permit the appointment of a counsel who

${ }^{102}$ ICTY Rule, supra note 1, at Rule 44.

${ }^{103}$ ICTY Rule, supra note 1 , Rule 45(A) reads:

(i) A list of counsel who speak one or both of the working languages of the Tribunal, meeting the requirements of Rule 44 and have indicated their willingness to be assigned by the Tribunal to indigent suspects or accused, shall be kept by the Registrar.

(ii) In particular circumstances, upon the request of an indigent suspect or accused, the Registrar may be authorised, by a Judge or a Trial Chamber seized of the case, to assign counsel who speaks the language of the suspect or the accused but who does not speak either of the two working languages of the Tribunal.

Paragraph (ii) was added after the guilty plea made by Erdemovic on May 31, 1996. It was not in IT/32/Rev.8 (as amended up to April 23, 1996), but was in IT/32/Rev. 9 (as amended up to July 5, 1996). 
speaks neither English nor French under special circumstances. Because of the importance of the assistance of counsel, the ICTY is under a duty to appoint a co-counsel who meets the language requirement in addition to other requirements.

The circumstances surrounding Erdemovic's guilty plea which was made when he was represented by counsel appear to indicate that the competence of the counsel is suspect. Three obvious facts suggest the Erdemovic might not have received effective counsel. First, he was permitted to plead guilty to a more serious charge, when faced with two alternative charges. Second, he was permitted to make a guilty plea while he was claiming that he was forced to do the horrid deeds. Finally, unofficial information from the ICTY indicates that his counsel did not speak either English or French. Not all facts are known at present as to the knowledge and experience of the counsel and as to the reason why he was chosen. Accordingly, it would be presumptuous to make any conclusion. It is, however, an issue that the ICTY should inquire into. Ineffective assistance of counsel is ground for post-conviction relief in many countries and should also be recognized at the ICTY.

\section{Erdemovic's Remedies}

As demonstrated, the guilty plea proceeding in the Erdemovic case was fraught with defects. These defects made Erdemovic's plea not a voluntary and intelligent one and thus caused substantial prejudice to Erdemovic. In common law jurisdictions, the accused is entitled to plead anew under such circumstances. ${ }^{104}$ Such a course should be adopted by vacating the Sentencing Judgement, remanding the case and giving Erdemovic a chance to re-plead.

\section{THE DEFENSES}

The second questionable aspect of the Sentencing Judgement is its treatment of the defenses raised by Erdemovic. The Trial Chamber understood the defenses as the defense of "obedience to superior orders" and the defense of "physical and moral duress accompanied by the order from a

${ }^{104}$ See, e.g., McCarthy v. United States, 394 U.S. 459, 463-64 (1969); R. v. Durham Quarter Sessions, ex parte Virgo, 1 All. E.R. 466 (1952); R. v. Ingleson, 1 K.B. 512 (1915). 
military superior" 105 and then proceeded to reject each of them. This Part will first sketch the status of these defenses under the ICTY Statute and then discuss the Trial Chamber's treatment of them, with particular emphasis on the defense of duress. This Part agrees with the Trial Chamber's decision rejecting obedience to superior orders as a defense, which accords with the state of the law. Finally, while agreeing with the Trial Chamber that duress may be a defense to a crime against humanity, this Part puts forward a new analysis and argues that duress should be recognized as a defense to murder as the predicate act for a crime against humanity but not to murder as the predicate act for an ordinary war crime.

\section{A. The Defenses under the ICTY Statute}

The Statute does not address defenses in general. This does not mean that the defenses are thus unavailable to defendants. On the contrary, paragraph 58 of the Report of the Secretary-General, which embodies the intent of the drafters, directs that "The International Tribunal itself will have to decide on various personal defences which may relieve a person of individual criminal responsibility, such as minimum age or mental incapacity, drawing upon general principles of law recognized by all nations." 106 The examples given are of course merely illustrative and not exhaustive. Therefore, if a defense is available under general principles of law, it should be available under the Statute.

The Statute specifically excludes obedience to superior orders as a defense. Article 7(4) of the Statute states that "[t]he fact that an accused person acted pursuant to an order of a Government or of a superior shall not relieve him of criminal responsibility, but may be considered in mitigation of punishment if the International Tribunal determines that justice so requires." Paragraph 57 of the Report of the Secretary-General states that "[o]bedience to superior orders may, however, be considered a mitigating factor .... For example, the International Tribunal may consider the factor of superior orders in connection with other defences such as coercion or lack of moral choice."107 While not crystal clear, this last sentence appears to recognize the possible existence of a defense of coercion or lack of moral choice separate from obedience to superior orders, and that the presence of superior

\footnotetext{
${ }^{105}$ Sentencing Judgement, supra note 1 , at paras. $15,16$.

${ }^{106}$ Report of the Secretary-General, UN Doc. S/25704, para. 58.

${ }^{107}$ Id. at para. 57.
} 
orders may be considered evidence of coercion or lack of moral choice.

It is questionable whether the Security Council may, by a resolution, that is, the Statute, exclude a defense if it is available under general principles of law. ${ }^{108}$ Its adventure in this area will only be on safe ground if it is merely a restatement of the law. ${ }^{109}$ It appears this is so with respect to the defense of obedience to superior orders. Article 7(4) is a copy of Article 8 of the Nuremberg Charter. ${ }^{110}$ Although the language of Article 8 appears to bar any defense associated with a superior order, the effect given to it by the International Military Tribunal at Nuremberg is somewhat narrower:

The provisions of this article are in conformity with the law of all nations. That a soldier was ordered to kill or torture in violation of the international law of war has never been recognized as a defense to such acts of brutality, though, as the Charter here provides, the order may be urged in mitigation of the punishment. The true test, which is found in varying degrees in the criminal law of most nations, is not the existence of the order, but whether moral choice was in fact possible. ${ }^{111}$

The "test" apparently refers to the test of criminal responsibility rather than of whether mitigation of punishment is appropriate. This is made clear by the French text, which uses the phrase "Le vrai criterium de la responsabili-

${ }^{108}$ See, e.g., Frederic L. Kirgis, Jr., The Security Council's First Fifty Years, 89 AM. J. INT'L L. 506 (1995); Keith Harper, Does the United Nations Security Council Have the Competence to Act as Court and Legislature? 27 N.Y.U. J. INT'L L. \& POL. 103 (1994).

109 The ICTY so far has asserted its power to review Security Council decisions in order to determine its jurisdiction under the theory "competence de la competence." Decision on the Defence Motion for Interlocutory Appeal on Jurisdiction, Prosecutor v. Tadic, Case No. IT-94-1-AR72 (ICTY, App. Ch., Oct. 2, 1995), at 5-11. This theory does not apply, a fortiori, to reviewing Security Council decisions on issues of substantive law. There is no bar, however, to inventing a new theory for this purpose, if the ICTY is so inclined. Contra Faiza Patel King, Sensible Scrutiny: The Yugoslavia Tribunal's Development of Limits on the Security Council's Power Under Chapter VII of the Charter, 10 EMORY INT'L L. REV. 509, 578 (1996) ("the Yugoslavia Tribunal may have precluded reviewability for non-jurisdictional challenges").

1101 Trial of the Major War Criminals before the International Military Tribunal 12 (Nuremberg, 1947) ("The fact that the defendant acted pursuant to order of his Government or of a superior shall not free him from responsibility, but may be considered in mitigation of punishment if the Tribunal determine [sic] that justice so requires.").

${ }^{111}$ Id. at 224. 
té."112 Scholars generally considered this statement as indicating that "the Tribunal expressed its willingness to consider the circumstance of obedience to orders as a factual element within the limits of a defence based on lack of moral choice, even though it denied this circumstance the status of defence per se."113 Not precluding a defense merely because it is associated with a superior order appears to be the necessary conclusion. Otherwise, an absurd result may obtain: a defendant has a defense if he was ordered at gun point to commit a crime by a peer or a subordinate, but not if so ordered by a superior.

When one borrows Article 8 of the Nuremberg Charter, it is reasonable to expect that the authoritative interpretation of that provision is also borrowed. Thus, Article 7(4) of the ICTY Statute should be interpreted as incorporating the construction of Article 8 of the Nuremberg Charter given by the International Military Tribunal at Nuremberg, the authoritative interpreter. So construed, Article 7(4) is in line with what scholars generally consider to be the state of the law. For example, Yoram Dinstein, after canvassing case law and scholarly writings, concluded that the fact of obedience to superior orders does not constitute a separate defense, but may be taken as within the scope of other defenses, namely, mistake of law and compulsion, if these defenses are available under international law. ${ }^{114}$ The International Law Commission appears to take the same position. Article 5 of its 1996 Draft

112 Procès des Grands Criminels de Guerre devant le Tribunal Militaire International, Nuremberg, Judgement, vol. 1, p. 236, as quoted in YORAM DINSTEIN, THE DEFENCE OF 'OBEDIENCE TO SUPERIOR ORDERS' IN INTERNATIONAL LAW 149 (1965).

113 Yoram DINSTEIN, THE DEFENCE OP 'OBEDIENCE TO SUPERIOR ORDERS' IN INTERNATIONAL LAW, 151 (1965). Dinstein himself disagreed with this view of the majority of scholars. He believed that the language in the Nuremberg Judgment meant that no consideration should be given to the fact of obedience to the orders. Id. at 150,233 . One of the reasons he gave for his disagreement is that the position of the majority of scholars assumes that the Tribunal departed from the Nuremberg Charter, which does not square with the explicit enunciation of the Tribunal itself. Dinstein may be incorrect. The Tribunal did not state what Dinstein believed. In addition, the Tribunal did in fact carefully refine the Nuremberg Charter, which was written in broad and loose language. See Norman Silber \& Geoffrey Miller, Toward "Neutral Principles" in the Law: Selections from the Oral History of Herbert Wechsler, 93 CoLUM. L. REV. 854, 900-01 (1993).

${ }^{114}$ Id. at 81 . He proposed to principlize these two defenses into a mens rea principle under which the "lack of mens rea, of which obedience to orders constitutes circumstantial evidence, serves to protect from criminal responsibility." Id. at 88. This principlization may not be completely accurate with respect to whether duress is a defense to ordinary murder or ordinary war crimes. See infra notes $140-147$ and accompanying text. 
Code $^{115}$ essentially copies Article 7(4) of the ICTY Statute, excluding the defense of obedience to superior orders, without expressly providing for a duress exception. However, Article 14 of the 1996 Draft Code provides that "[t]he competent court shall determine the admissibility of defences in accordance with the general principles of law, in the light of the character of each crime." 116 This provision obviously permits the defense of duress or coercion if viable under general principles of law. Furthermore, the ILC in a commentary states that "[s]uperior orders may ... sometimes be relevant in relation to the separate issue of duress or coercion."117

Without being overly sophisticated, we can take duress, coercion, compulsion or "lack of moral choice" as stating the same defense. ${ }^{118}$ There may be minute distinctions between them, but too much sophistication will make the law inaccessible to the ordinary persons who are supposed to be governed by it. Taken as a whole, the Statute and the Report of the Secretary-General exclude the claimed defense of obedience to superior orders, but permit the defense of duress if it is available under general principles of law. That is, if duress is otherwise available as a defense, it does not disappear merely because a superior order caused the duress.

\section{B. The Sentencing Judgement's Treatment of the Defenses}

According to the Trial Chamber, "to explain his conduct, the accused argued both an obligation to obey the orders of his military superior and physical and moral duress stemming from his fear for his own life and that of his wife and child."119 The Trial Chamber then rejected obedience to superior orders as a defense, treating it as a mitigating circumstance in

1151996 Draft Code, supra note 39, at art. 5.

${ }^{116}$ Id. at art. 14.

${ }^{117}$ Id. at art. $14 \mathrm{cmt} .9$.

${ }^{118}$ Cf. Albin Eser, "Defences" in War Crime Trials, 24 ISR. Y.B. HUM. RTs. 201, 213-14 (1994).

${ }^{119}$ Sentencing Judgement, supra note 1, at para. 14. In his Notice of Appeal, Erdemovic argues that the Trial Chamber should have obtained a psychologist's report on his mental state at the time of commission of the alleged crime and that he was in a state of mental shock at that time. See Notice of Appeal by the Defence, supra note 24, at 7. Erdemovic appears to be raising the defense of diminished capacity. But his confession shows that he made a deliberate choice to save his life and that of his family by following the order to kill, thus contradicting his argument that he was under a mental shock and could not make a choice. As the Trial Chamber did not discuss this defense, I will not further discuss it here. 
determining the penalty at most. ${ }^{120}$ This ruling is consistent with the Statute and the current state of the law as discussed above and, of course, unquestionable.

The Trial Chamber's treatment of duress as a defense, however, is confusing and unsatisfactory. According to the Trial Chamber, Erdemovic raised the defense of "physical and moral duress accompanied by the order from a military superior."121 This term appears to be the creation of the Trial Chamber and the concept can be more accurately described by substituting "caused by" for "accompanied by." In essence, it is the same as "duress." According to the Trial Chamber, the Statute provides no guidance on this defense and paragraph 57 of the Report of the SecretaryGeneral seems to regard it as a mitigating circumstance at most. ${ }^{122}$ Such a reading of paragraph 57 is not accurate. Nothing in the language of this paragraph implies that duress is merely a mitigating circumstance. To the contrary, that paragraph appears to recognize the possible existence of a defense of coercion or lack of moral choice separate from obedience to superior orders, as discussed above. Moreover, the Trial Chamber failed to point to paragraph 58 of the Report of the Secretary-General, which commands the Tribunal to look to general principles of law to decide whether a defense is available.

Nevertheless, the Trial Chamber recognized the possible application of the defense of duress. The Trial Chamber first noted that the United Nations War Crimes Commission found that the post-World War Two military tribunals of nine nations considered duress as a complete defense and quoted the Commission's formulation of the essential conditions for the application of this defense. These conditions are (1) "the act charged was done to avoid an immediate danger both serious and irreparable"; 123 (2) "there was no adequate means of escape"; ${ }^{124}$ and (3) "the remedy was not disproportionate to the evil."125 After some further discussion of the post-World War Two military tribunal case law that characterized the absence of moral choice as an essential criterion and that took into account the voluntary participation in the enterprise which led to the undesirable result, the Trial Chamber concluded:

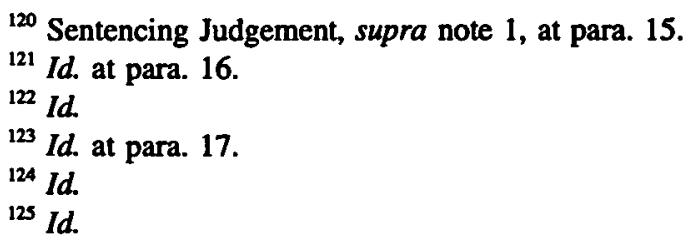


19. Accordingly, while the complete defence based on moral duress and/or a state of necessity stemming from superior orders is not ruled out absolutely, its conditions of application are particularly strict. They must be sought not only in the very existence of a superior order- which must first be proven- but also and especially in the circumstances characterising how the order was given and how it was received. In this case-by-case approach- the one adopted by these post-war tribunals- when it assesses the objective and subjective elements characterising duress or the state of necessity, it is incumbent on the Trial Chamber to examine whether the accused in his situation did not have the duty to disobey, whether he had the moral choice to do so or to try to do so. Using this rigorous and restrictive approach, the Trial Chamber relies not only on the general principles of law as expressed in numerous national laws and case-law, but would also like to make clear through its unfettered discretion that the scope of its jurisdiction requires it to judge the most serious violations of international humanitarian law.

With regard to a crime against humanity, the Trial Chamber considers that the life of the accused and that of the victim are not fully equivalent. As opposed to ordinary law, the violation here is no longer directed at the physical welfare of the victim alone but at humanity as a whole.

20. On the basis of the case-by-case approach and in light of the elements before it, the Trial Chamber is of the view that proof of the specific circumstances which would fully exonerate the accused of his responsibility has not been provided. Thus, the defence of duress accompanying the superior order will, as the Secretary-General seems to suggest in his report, be taken into account at the same time as other factors in the consideration of mitigating circumstances. ${ }^{126}$

The Trial Chamber's rejection of the defense of duress is thus based on the lack of proof on the part of Erdemovic. As discussed elsewhere in this

${ }^{126}$ Id. at paras. 19, 20 (footnotes omitted). The Trial Chamber appeared to treat duress and "a state of necessity" as the same defense, which to some extent is reasonable, see Albin Eser, supra note 118, at 212 (para. 2). I will thus not discuss necessity separately, although there may be distinctions between necessity and duress. 
Essay, this conclusion is susceptible to attack on procedural ${ }^{127}$ and evidential $^{128}$ grounds. The Trial Chamber's elaboration of the law relating to the availability of the defense of duress does not fare any better. It is confusing and unsatisfactory.

First of all, it is not clear why the Trial Chamber believed it important that it "would also like to make clear through its unfettered discretion that the scope of its jurisdiction requires it to judge the most serious violations of international humanitarian law." 129 One is hard pressed to explain why the nature and scope of jurisdiction has anything to do with substantive law relating to the defenses, although the defenses may be related to the substantive crimes. The law does not appear to permit a court to eliminate a defense simply because its jurisdiction is to adjudicate serious crimes.

Second, although the Trial Chamber appeared to apply the test put forward by the United Nations War Crimes Commission, it did not do so faithfully. The third element of that test, if given any effect, would appear to bar duress as a defense to ordinary murder, not to mention a crime against humanity. As the ILC pointed out,

There are different views as to whether even the most extreme duress can ever constitute a valid defence or extenuating circumstance with respect to a particularly heinous crime, such as killing an innocent human being. This question requires consideration of whether an individual can ever be justified in taking the life of one human being in order to save another human being or, in other words, whether the remedy of saving a human being is inherently disproportionate to the evil of killing another human being under the third element. ${ }^{130}$

If the third element is a valid and necessary one, and if we believe that one life is equal to another, duress cannot be a defense to the taking of another innocent life, because the remedy is at most equal to the evil, not to mention the 70 victims whom Erdemovic confessed to having killed. With respect to a crime against humanity, the Trial Chamber correctly pointed out that "the life of the accused and that of the victim are not fully equivalent. As opposed to ordinary law, the violation here is no longer directed at the

\footnotetext{
${ }^{127}$ See supra Part II.B.5.

${ }^{128}$ See infra Part IV.

129 Sentencing Judgement, supra note 1, at para. 19.

1301996 Draft Code, supra note 39, at art. $14 \mathrm{cmt} .10$.
} 
physical welfare of the victim alone but at humanity as a whole."131 However, it did not based its rejection of the defense on this ground. Rather, it rejected the defense for lack of proof of the specific circumstances that would exonerate Erdemovic. The import of this statement in the Trial Chamber's decision is thus unclear.

Third, the heavy reliance by the Trial Chamber on the post-World War Two military tribunal case-law and its failure to canvass and take into account the current state of general principles of law is questionable. ${ }^{132}$ The military tribunal case-law did not appear to actually establish a clear rule on duress as a defense to murder, which is the underlying crime that Erdemovic is charged with and convicted of. The United Nations War Crimes Commission recited and relied merely on certain statements in the military tribunal cases, rather than the actual holdings. ${ }^{133}$ Finally, the passage of 50 years since those cases were decided should prompt one to ascertain what the current state of the law is, as things may have changed. Indeed, Paragraph $58^{134}$ of the Report of the Secretary-General directs the Tribunal to apply general principles of law and thus would require the Tribunal to survey them. This the Trial Chamber did not do. While it stated that it relied upon "general principles of law as expressed in numerous national laws and case-law", ${ }^{135}$ it did not analyze these principles. It merely quoted, in a footnote, from the new penal code of one country, and cited to its case-law. ${ }^{136}$

Fourth, the Trial Chamber did not meaningfully analyze duress as a defense in light of the characteristics of crime against humanity. The importance of such a mode of analysis is recognized by the ILC in Article 14 of its 1996 Draft Code, which commands the courts to "determine the admissibility of defences in accordance with the general principles of law, in the light of the character of each crime."137 In its discussion of duress as a defense, the Trial Chamber never once analyzed the elements of crime

${ }^{131}$ Sentencing Judgement, supra note 1, at para. 19.

132 The ILC's commentary on duress, see 1996 Draft Code, supra note 39, at art. $14 \mathrm{cmt}$. 10 , may be criticized on the same ground.

133 See XV United Nations War Crimes Commission, Law Reports of Trials of War Criminals 170-75 (1949).

134 The Trial Chamber did not mention this paragraph, although it mentioned paragraph

57. See Sentencing Judgement, supra note 1 , at paras. $15,16$.

${ }^{135}$ Id. at para. 19.

${ }^{136}$ Id. at n.13.

${ }^{137} 1996$ Draft Code, supra note 39, at art. 14. 
against humanity and how duress might have affected each or some of them. ${ }^{138}$ While the Trial Chamber mentioned that with regard to a crime against humanity, the life of the accused and that of the victim are not fully equivalent and that a crime against humanity is not merely directed at the physical welfare of the victim alone but at humanity as a whole, ${ }^{139}$ it did not make clear what role this played in its decision.

In sum, the Trial Chamber's elaboration of the law relating to duress as a defense leaves one unsatisfied. Recognizing duress as a defense to a crime against humanity is a correct position, but better analysis is yet to be found.

\section{A Proposed Treatment of Duress as a Defense}

To provoke debate on this issue, I propose that duress be treated as a complete defense to crimes against humanity but not to ordinary war crimes, even where the underlying act alleged for both crimes is murder. This proposed treatment accords generally with the current state of general principles of law and takes into account the characteristics of the different crimes.

While a comprehensive survey of general principles of law is difficult, it is fair to say that it is debatable whether duress is solidly established as a defense to ordinary murder. ${ }^{140}$ The law in major legal systems seldom has difficulty in treating duress as a defense in general. ${ }^{141}$ It is murder that these legal systems have problems with, and they have little, if any, experience in dealing with duress as a defense to a crime against humanity. The common law rule is that duress is no defense to murder. ${ }^{142}$ Several strands of argument have been advanced in favor of this rule. The first denies that "the ordinary man of reasonable fortitude is not to be supposed to be capable of heroism if he is asked to take an innocent life rather than sacrifice his own." 143 The second rejects the view the "duress as defense

138 Sentencing Judgement, supra note 1, at paras. 11-21.

${ }^{139}$ Id. at para. 19.

${ }^{140}$ See, e.g., Eser, supra note 118; M. CHERIF BASSIOUNI, CRIMES AGAINST HUMANITY IN INTERNATIONAL CRMMINAL LAW 438 (1992); GEORGE FletCHER, RETHINKING CRIMINAL LAW 829-35 (1978); Abbe L. Dienstag, Fedorenko v. United States: War Crimes, the Defense of Duress, and American Nationality Law, 82 ColuM. L. REv, 120 (1982).

${ }^{141}$ See FLETCHER, supra note 140.

${ }^{142}$ Regina v. Howe, 1 A.C. 417 (1987), 1 All E.R. 771 (1987).

${ }^{143}$ Id. at 432 (op. of Lord Hailsham, L.C.). 
affects merely the existence or absence of mens rea,"144 believing that "the decision of the threatened man whose constancy is overborne so that he yields to the threat, is a calculated decision to do what he knows to be wrong, and is therefore that of a man with, perhaps to some exceptionally limited extent, a 'guilty mind.' "145 Under such circumstances, one may well say that the choice on the part of the defendant has a highly deliberate quality. Indeed, Erdemovic appeared to be of such a case. He deliberately chose to kill others in order to save his own life and that of his family. Of course, this view recognizes that such a threatened man is less guilty than one who kills but under no constraint. ${ }^{146}$ For such a less guilty man, mitigation of punishment is sufficient. The third strand of argument treats duress as an issue of justification, asserting that one innocent life is at least as valuable as that of the threatened man who cannot thus claim that he is choosing the lesser of two evils. ${ }^{147}$ This is obviously the third element of the test put forward by the United Nations War Crimes Commission.

A small number of common law jurisdictions have begun to permit duress as a defense by statute, due to Section $2.09^{148}$ of the Model Penal Code promulgated by the American Law Institute. ${ }^{149}$ Moreover, the broad language in the penal codes of civil law countries such as Germany ${ }^{150}$ and

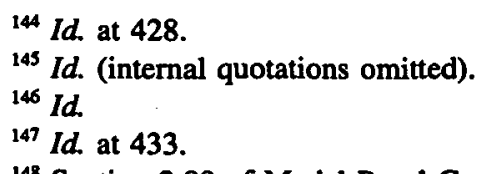

${ }^{148}$ Section 2.09 of Model Penal Code provides, in part:

(1) It is an affirmative defense that the actor engaged in the conduct charged to constitute an offense because he was coerced to do so by the use of, or a threat to use, unlawful force against his person or the person of another, that a person of reasonable firmness in his situation would have been unable to resist.

(2) The defense provided by this Section is unavailable if the actor recklessly placed himself in a situation in which it was probable that he would be subjected to duress. The defense is also unavailable if he was negligent in placing himself in such a situation, whenever negligence suffices to establish culpability for the offense charged.

${ }^{149}$ See FlETCHER, supra note 140, at 831 \& $\mathrm{n.72}$ (arguing that the statutes of some jurisdictions modeled after the Model Penal Code would permit duress as a defense to murder). The American Law Institute provides that while six states allow for broad defense of duress, many jurisdictions exclude murder from such a defense. MODEL PENAL CODE \& 2.09 cmt. 4 \& nn. 53 \& 54 (1985).

${ }^{150}$ The German Criminal Code, $835(1)$ StGB provides:

If someone commits a wrongful act in order to avoid an imminent, otherwise unavoidable danger to life, limb, or liberty, either to himself or to a dependent or someone closely connected with him, the actor commits the act without culpability. 
France ${ }^{151}$ may be construed as permitting such a defense, although judicial application is not crystal clear. The essential basis for this rule is the recognition that there is a point where a person of reasonable firmness in a situation will be unable to resist the unlawful force. This has become the test to measure whether duress exists. Under such circumstances, neither utilitarian nor restributivist theories can justify denying duress as a defense to murder. ${ }^{152}$ As the American Law Institute stated,

law is ineffective in the deepest sense, indeed ... hypocritical, if it imposes on the actor who has the misfortunate to confront a dilemmatic choice, a standard that his judges are not prepared to affirm that they should and could comply with if their tum to face the problem should arise. Condemnation in such a case is bound to be an ineffective threat; what is, however, more significant is that it is divorced from any moral base and is unjust. ${ }^{153}$

Finally, treating duress as an excuse, theorists have argued that, although the threatened man had intended to kill, he was not given a fair opportunity to make his choice. ${ }^{154}$ Thus, the choice at best represents a "limited, temporal distortion of the actor's character."155 Under such circumstances, recognizing duress as a defense is a concession to human frailty, without regard to whether the remedy is proportionate to the evil. This is the discernible trend moving away from treating duress as "justification" to

This is not the case if under the circumstances it can be fairly expected of the actor that he suffer the risk; this might be fairly expected of him if he caused the danger, or if he stands in a special legal relationship to the danger. In the latter case, his punishment may be mitigated in conformity with $\S 49(1)$.

Translated in FLETCHER, supra note 140, at 833.

I5! The 1994 French Penal Code provides that "a person acting under force or duress which he could not resist shall not be held criminally responsible", C.PéN art. 122, and that "a person who in the face of a present or imminent danger which threatens him, someone else or property or who commits an act necessary to preserve his life or property shall not be criminally responsible unless a disproportion exists between the means employed and the gravity of the threat", C.PEN arts. 122-27 (unofficial translation appears in Sentencing Judgement, supra note 1 , at para. 19 n.13.).

${ }^{152}$ See Dienstag, supra note 140.

153 MODEL PENAL CODE $\$ 2.09$ cmt. 2 (1985).

154 JOSHUA DRESSLER, UNDERSTANDING CRMMNAL LAW 278 (2d ed. 1995); cf. H.L.A. HART, PUNISHMENT AND RESPONSIBIITY 201 (1992).

${ }^{155}$ FLETCHER, supra note 140 , at 802. 
treating it as "excuse." This would take the third element of the test put forward by the United Nations War Crimes Commission out of consideration.

This brief discussion reveals that general principles of law have not yet clearly established duress as a defense to murder. The arguments for and against such a defense are both strong. I believe, however, that the characteristics of an ordinary war crime tip the balance against providing such a defense to murder as the predicate act for the ordinary war crime at issue. First of all, although not completely clear, it appears that an ordinary war crime is a general intent crime, thus requiring only the intent to kill for murder. When the defendant actually made, under duress, a deliberate choice to kill in order to save his life, he still has a guilty mind, though a reduced one, which still meets the intent requirement. Accordingly, he may still be justly punished, but perhaps not too much. The temporal distortion of his character perhaps should not exonerate him completely. Duress therefore is an issue of mitigation of punishment. Secondly, the standard of reasonable firmness may be, justifiably, revised upward for those who participate, as combatants, in armed conflicts. Because of their training and the nature of their profession, they are expected to have greater resistance than an ordinary person. Many a man are trained to, and often do, jump in front of the protected target when necessary. Thus, it seems reasonable to require that a combatant be able to resist any threat. If a particular combatant cannot achieve such a level of resistance, it is his own fault and he cannot complain about being convicted of a crime of general intent. Perhaps such a person should not participate in armed conflicts. In any event, mitigation is available to take account of his reduced responsibility.

Finally, the rule permitting duress as a defense has some exceptions that indicate the fact that the defendant could not resist the unlawful force does not always exonerate him. ${ }^{156} \mathrm{He}$ can lose the defense if he plays a part in causing the duress. Or he can lose the defense "if under the circumstances it can be fairly expected of the actor that he suffer the risk; this might be fairly expected of him if he caused the danger, or if he stands in a special legal relationship to the danger."157 These exceptions can be applied to a combatant who participates in armed conflicts. By virtue of his participation in armed conflicts, he thus can be said to play a role in causing the duress. He can also be expected to bear the risk because of the special position as

${ }^{156}$ E.g., MODEL Penal CODE $\$ 2.09$ (2) (1985).

${ }^{157}$ German Criminal Code, supra note 150. 
a combatant, bearing a relationship to the danger and shouldering a special duty to protect various targets such as civilians. ${ }^{158}$ Thus, it is fair to expect the participants in armed conflicts to bear the risk. This does not appear to be a controversial position. As a general proposition, H.L.A. Hart articulated the concept of "role responsibility." 159 Under that concept, playing a particular role in society gives rise to corresponding responsibility. More specifically, George Fletcher argued that under the exception in Section 35(1) of the German Criminal Code, if the defendant "occupies a special office, such as that of police officer or soldier, more may be expected of him than from ordinary citizens." 160 Clearly, these exceptions are in conflict with the theory of "excuse" and are based on a form of "justification." George Fletcher considered these provisions as synthesizing "duress" and "necessity", permitting the law "to transcend the particularities of threats in cases of duress and locate duress in a broader normative theory of fair social demands." can be fairly expected to resist human threats, but whether he can fairly expect to abstain from an act that seems required under the circumstances." 162 This theory supports the position that a combatant should not enjoy duress as a defense to an ordinary war crime.

However, duress should be a defense to murder if it is said to be the predicate act for a crime against humanity because of the special characteristics of the crime. ${ }^{163}$ It is recognized that a crime against humanity is a specific intent crime. That specific intent is negated by duress. It is true that Article 5 of the ICTY Statute does not provide for such a specific intent. We must bear in mind, however, that this definition is essentially a copy of the same definition in the Nuremberg Charter. ${ }^{164}$ The Nuremberg Charter

158 See Oren Gross, The Grave Breaches System and the Armed Conflict in the Former Yugoslavia, 16 Mich. J. INT'L L. 783 (1995), for a description of the special duties under the Geneva Conventions.

159 HART, supra note 154 , at $212-14$.

${ }^{160}$ FLETCHER, supra note 140 , at 833.

${ }^{161}$ Id. at 833-34.

162 Id. at 834.

163 The same would appear to apply to genocide, although not relevant in the Erdemovic case, because genocide requires the specific intent "to destroy, in whole or in part, a national, ethnic, racial or religious group, as such." ICTY Statute, supra note 1, at art. 4.

${ }^{164}$ Nuremberg Charter, art. 6(c) ("CRIMES AGAINST HUMANITY: namely, murder, extermination, enslavement, deportation, and other inhumane acts committed against any civilian population ..."). 
definition was somewhat refined by the International Military Tribunal at Nuremberg. Taking account of the work of that Tribunal, the ILC restated the definition as: "A crime against humanity means any of the following acts, when committed in a systemic manner or on a large scale and instigated or directed by a Government or by any organization or group: . . . a. murder .165 This refinement should be incorporated into Article 5 of the ICTY Statute. Indeed, Trial Chamber I itself appeared to formulate crime against humanity in a similar fashion in its Rule 61 decision in the Nikolic case, ${ }^{166}$ which was decided before the ILC published its 1996 Draft Code.

Under this refined definition, to constitute a crime against humanity, the act must have been either committed pursuant to a preconceived plan or against multiple victims ${ }^{167}$ and must have been "instigated or directed by a Government or by any organization or group."168 The "flip side" of this requirement is that the defendant must have willingly endorsed and followed such instigation or direction. This form of specific intent is one level beyond the physical act of killing, when the underlying crime is murder. It goes to the policy implementation and realization level. This is a paradigmatic ulterior motive, which is irrelevant to crimes of general intent, but is the sine qua non of crimes of specific intent. ${ }^{169}$ This necessarily requires that the act on the part of the defendant become part of the wilful implementation or realization of the policy of a Government or organized group. That is, there must be wilful convergence between the intent of the actor and the instigation or direction of a Government or group. This convergence requirement is to preclude the acts of a lone criminal acting for his own selfinterest from being considered crimes against humanity. ${ }^{170}$ While not

1651996 Draft Code, supra note 39, at art. 18.

${ }^{166}$ Decision of Trial Chamber I-Review of Indictment Pursuant to Rule 61, Prosecutor v. Nikolic, Case No. IT-95-2-R61 (ICTY, Trial Ch. I, Oct. 20, 1995). "The second circumstance, whereby crimes must be 'directed against any civilian population' is specific to crimes against humanity. Set forth in broad terms in the Statute, it covers, according to prevailing opinion, three distinct components. First, the crimes must be directed at a civilian population, specifically identified as a group by the perpetrators of those acts. Secondly, the crimes must, to a certain extent, be organised and systematic. Although they need not be related to a policy established at State level, in the conventional sense of the term, they cannot be the work of isolated individuals alone. Lastly, the crimes, considered as a whole, must be of a certain scale and gravity." Id.

1671996 Draft Code, supra note 39, at art. $18 \mathrm{cmts} .3 \& 4$.

${ }^{168}$ Id. at art. 18 \& cmt. 5.

169 See DRESSLER, supra note 154, at 106-07, 118-20.

170 Supra note 168. 
stated by the ILC, such a requirement appears to address the "system criminality" as articulated by Bert V.A. Röling, ${ }^{171}$ in order to elevate crimes against humanity to an issue of the responsibility of a system, rather than merely the responsibility of an individual. In this sense, collective responsibility is part of the focus. Without such a focus, the concept of crimes against humanity would be cheapened to that of an ordinary crime.

When duress or coercion is found to exist, it would transform instigation or direction into overwhelming force which causes the actor to commit the act for a selfish purpose other than the import of the instigation or direction, leading to a divergence between the intent of the actor and the instigation or direction of the Government or group. The specific intent for a crime against humanity is thus negated. The crime, if any, becomes the crime of a lone criminal committed for his own self interest of saving his life and limb, ${ }^{172}$ as far as the actor under duress is concerned, although the person exerting the duress may be separately punishable for a crime against humanity. When a threatened man kills others to save his own life under irresistible duress either under the reasonable firmness standard or a heightened standard, his act does not constitute part of the wilful implementation or realization of the policy of a Government or a group, although he may have become an unthinking tool in the process. He merely intends to save his own life. For the defendant under duress, it does not matter to him what purpose the unlawful force is supposed to serve and cannot think of endorsing or participating in that purpose, although as a by-product of saving his life, his act causes some physical implementation of the policy unintended by him. Accordingly, he lacks the specific intent required for a crime against humanity.

A theoretical expectation that the defendant bears the risk of the duress regardless of whether he in fact cannot resist the coercion may be justified when a crime of general intent requiring a simple intent to kill is concerned, but not when a specific intent going beyond the killing to the policy realization is at issue. Under the latter circumstances, duress serves to negate the specific intent and should be a defense. This is particularly true in the case of Erdemovic who claimed that he did not know about the purpose of

${ }^{171}$ See, e.g., Bert V.A. Röling, Aspects of the Criminal Responsibility for Violations of the Laws of War, in THE NEW HUMANITARIAN LAW OP ARMED CONFLICT 199, 203-04 (Antonio Cassese ed., 1979).

${ }^{172}$ Cf. Opinion and Judgement, Prosecutor v. Tadic, Case No. IT-94-1-T (ICTY, Trial Ch. II, May 7, 1997), paras. 656-59. 
the mission until he arrived at the killing field and was ordered to murder the victims. He did not know about the policy of perpetrating atrocities against the civilians in advance and was not willing to participate in it. His first reaction was refusing to obey. He committed the acts only to save his life and that of his family. ${ }^{173}$

In summary, general principles of law have not yet clearly established duress as a defense to murder. The character of ordinary war crimes militates in favor of denying such a defense to murder as an ordinary war crime. The specific intent required for a crime against humanity, however, is lacking when murder is committed under duress. This requires that duress be recognized as a defense to a crime against humanity where the underlying crime is murder.

\section{THE EVIDENCE}

The third questionable aspect of the Sentencing Judgement is its treatment of the evidentiary issues. In rejecting Erdemovic's defense of duress, the Trial Chamber stated that it was "of the view that proof of the specific circumstances which would fully exonerate the accused of his responsibility has not been provided."174 This implies that in the view of the Trial Chamber Erdemovic should bear the burden of proof ${ }^{175}$ on the defense and that the Trial Chamber disregarded Erdemovic's statements that he was coerced into committing the alleged crime. Moreover, the Trial Chamber appeared to apply a form of collateral estoppel or issue preclusion against Erdemovic in another paragraph in the Sentencing Judgement. These treatments of evidentiary issues are dubious at best.

Erdemovic's guilty plea raises the question whether normal evidentiary rules still apply. However, once the Trial Chamber thought that proof of the defense was necessary, it seems reasonable to require that the defense of duress be proved or disproved pursuant to the normal rules. From this perspective, this Part argues that once Erdemovic put forward some evidence

${ }^{173}$ See supra notes 3-6 and accompanying text.

174 Sentencing Judgement, supra note 1 , at para. 20. When discussing the issue of mitigating circumstances, the Trial Chamber stated that "the Defence has produced no testimony, evaluation or any other elements to corroborate what the accused has said. For this reason, the Judges deem that they are unable to accept the plea of extreme necessity." Id. at para. 91.

175 While realizing that this issue may actually be related to criminal procedure or even substantive law, I will treat it as an evidentiary question here. 
to raise the issue of duress, the Prosecutor should bear the burden of disproving it. Moreover, the Trial Chamber's disregarding Erdemovic's statements relating to duress is unexplained and unprincipled. Finally, collateral estoppel should not be applied against the accused to establish an element of the crime.

\section{A. Burden of Proof on the Defense of Duress}

While it is clear that under the ICTY Statute and the Rules the Prosecutor bears the burden of proof with respect to the elements of the crime beyond a reasonable doubt, ${ }^{176}$ it is not completely clear who should bear the burden of proof with respect to the defenses in general and with respect to duress in particular. While it is difficult to argue for a general rule applicable to all defenses, which I am not attempting to do here, several factors militate in favor of having the accused produce a modicum of proof sufficient to raise the issue of duress and then having the Prosecutor bear the burden of persuasion to disprove duress as a defense to a crime against humanity.

Under the Rules, the Tribunal is not bound by any national rules of evidence. ${ }^{177}$ However, in cases not provided for under the Rules, "a Chamber shall apply rules of evidence which will best favour a fair determination of the matter before it and are consonant with the spirit of the Statute and the general principles of law." ${ }^{178}$ Accordingly, national rules of evidence, as evidence of general principles of law, may inform the decision of the Tribunal. Under civil law, the judges themselves have a duty to search for the truth and the evidence, ${ }^{179}$ not to mention the prosecutor. Having broad powers to order production of evidence, ${ }^{180}$ the ICTY appears closer to the civil law model.

The American Law Institute's Model Penal Code provides that, when an affirmative defense relates to an element of the offense, the defendant bears the initial burden of producing some evidence tending to support the defense

${ }^{176}$ ICTY Statute, supra note 1, at art. 21(3); ICTY Rule, supra note 1, at Rule 87(A).

17 ICTY Rule, supra note 1, at Rule 89(A).

${ }^{178}$ Id. at Rule 89(B).

${ }^{179}$ See, e.g., ANDREA RAUBER, PROCEDURE AND EVIDENCE IN INTERNATIONAL CrmMnal TRIBUNALS 43-45 (1996) (unpublished D.E.S. Memoire on file with the Geneva Graduate Institute for International Studies).

${ }^{180}$ ICTY Rule, supra note 1, at Rule 98. 
and then the prosecution is required to disprove it and bears the burden of persuasion on the disproof. ${ }^{181}$ This may be reasonable especially when a defense such as duress is particularly within the knowledge of the defendant. Specifically with respect to duress as a defense to ordinary crimes, the statutes in several common law jurisdictions are split, "some placing the burden of proof as well as the burden of coming forward on the defendant who claims duress, and others following the [Model Penal] Code in keeping the burden of persuasion on the prosecution."182 Moreover, the British Law Commission has proposed that "it shall be for the prosecution to prove that the defence of duress does not apply, but only if there is sufficient evidence to raise an issue with respect to whether or not it does." 183 Taking both civil law and common law into consideration, it appears that the weight of the authority is in favor of placing the burden of persuasion on the prosecution to disprove duress.

More importantly, the special characteristics of a crime against humanity would appear to require placing on the prosecution the burden of disproving duress. Once the defendant claims, and produces some evidence to support the claim, that he was compelled to kill with the intent to save his own life, the specific intent required for a crime against humanity can be said to be non-existent. Since the prosecution is clearly required to establish the specific intent, it must therefore disprove the existence of an element that would negate that specific intent in order to meet its prosecutorial burden of proving the specific intent.

For these reasons, the Trial Chamber is incorrect in ruling that the circumstances proving the defense of duress have not been provided. The defendant should be required to provide only some minimal amount of evidence sufficient to raise or tending to prove his claim of duress, which Erdemovic has done by recounting the events and naming the officers giving the order to him. Moreover, one may ask why the Trial Chamber did not exercise its broad power to order production of evidence by requiring the prosecution to produce the officers who allegedly gave the order to kill to testify whether they actually gave the orders.

${ }^{181}$ Model Penal Code $\S 1.12$ \& cmt. 3 (1985).

${ }^{182}$ Id. $\S 2.09$ cmt. 4 (1985).

${ }^{183}$ Law Commission Report, Criminal Law, Report on Defences of General Application (Law Com. No. 83), Appendix 1, at 56. 


\section{B. Disregarding Erdemovic's Statements relating to Duress}

In his various statements, Erdemovic recounted the events leading to the alleged crime and those surrounding his claimed duress. The Trial Chamber adopted his version of the events relating to the acts he confessed to having committed, but disregarded his version of the events relating to his claim of duress. The Trial Chamber did not provide an explanation for this treatment of Erdemovic's statements and this is inexplicable.

The Trial Chamber stated that "some credibility may be given to the overall account of the accused." ${ }^{24}$ Erdemovic's statements relating to his alleged crime were sufficient for the Trial Chamber to convict him, as there was no other proof, and were relied upon in another important case. ${ }^{185}$ The Trial Chamber, however, did not give any credibility to his statements relating to his claimed defense of duress, without giving a reason or pointing to any specific evidence evincing his lack of credibility. Indeed, Erdemovic's statements were un-controverted. The Trial Chamber's silence on this point breeds speculation as to whether the Trial Chamber was resorting, sub silentio, to the amateurish belief that one may lie when he says good things about himself but never lies when he says bad things about himself. If this is what motivated the Trial Chamber's decision, it should have obtained expert opinion as to the validity of such a belief. It is in itself not a valid theory that a judicial tribunal should rely upon, without more, in serious business such as sending a person to jail.

Moreover, the Trial Chamber stated that Erdemovic produced no evidence corroborating what he said. However, his wounds and his stay at hospitals for injuries resulted from retaliation for his attempt to disobey appear to be corroboration of his claim of duress in general, indicating the coercive environment and pressure he was under. ${ }^{186}$ The Trial Chamber ignored the implication of such evidence.

In short, the Trial Chamber's treatment of Erdemovic's statements is highly questionable. It is unexplained and unprincipled. It smacks of applying a double standard, unbecoming a judicial panel.

\footnotetext{
184 Sentencing Judgement, supra note 1, at para. 90.

${ }^{185}$ Supra note 22 and accompanying text.

${ }^{186}$ Supra note 6 and accompanying text.
} 


\section{Collateral Estoppel}

The Trial Chamber stated that it "reaffirms that there is no valid reason for discussing the charge of crime against humanity since Drazen Erdemovic pleaded guilty to this count. Furthermore, all the facts relating to the fall of Srebrenica in which the accused played a part were characterized as a crime against humanity inter alia in the case against Radovan Karadzic and Ratko Mladic in the decision of 11 July 1996 which, pursuant to Rule 61 of the Rules, this Trial Chamber rendered."187 Although not completely clear, this statement appears to apply, perhaps unconsciously, a form of collateral estoppel against Erdemovic. That is, the facts relating to a crime established in one case are taken as necessarily proven in another. ${ }^{188}$ This violates fair criminal procedure.

The Trial Chamber's statement indicates confusion with respect to substantive law. It apparently believed that once a person is involved in a crime against humanity, he himself must have also committed that crime. It may not be necessarily true. As argued above, Erdemovic was forced to kill to save himself and his family, did not share the policy of his superiors and, therefore, did not have the specific intent for a crime against humanity. Moreover, in the Karadzic case, Erdemovic was not an indictee and was not found to have committed any crime and, therefore, there are no facts about Erdemovic's guilt to be taken as proven in the Erdemovic case.

Another important point is that the standard of proof in the two cases are different. The Rule 61 decision regarding Karadzic and Mladic did not involve a conviction. There the Trial Chamber need only be satisfied that "there are reasonable grounds for believing that the accused has committed all or any of the crimes" 189 to reconfirm the indictment and to issue an international warrant. In order to convict a defendant in a normal case, which I believe applies to the Erdemovic case because the Trial Chamber agreed that a defense was raised although he allegedly pleaded guilty, a majority of the Trial Chamber must be "satisfied that guilt has been proved beyond reasonable doubt." 190 A fact proved by a "reasonable grounds" standard cannot satisfy the "beyond reasonable doubt" standard and therefore

${ }^{187}$ Sentencing Judgement, supra note 1 , at para. 83.

${ }^{188}$ For an introduction to the concept of collateral estoppel, see RESTATEMENT (SECOND) OF JUDGMENTS $\$ 27 \mathrm{cmt}$. b (1980).

${ }^{189}$ ICTY Rule, supra note 1, at Rule 61(C).

${ }^{190}$ Id. at Rule 87(A). 
should not be considered to have been proved in the Erdemovic case.

Finally, even if the standard is the same, it goes against fair procedure to apply collateral estoppel to establish an element of the crime. While collateral estoppel is routinely applied in civil matters, the weight of authority is against applying it in a criminal case to establish an element of the crime. ${ }^{191}$ A trier of facts should consider evidence in each criminal case afresh, unencumbered by any previous findings or preconceptions. This appears to be the rule in the United States ${ }^{192}$ and the United Kingdom ${ }^{193}$ and should also apply in the ICTY, as it represents a good conception of faimess in criminal trials.

\section{CONCLUSION}

The issues raised in the Sentencing Judgement are hefty ones. A proper resolution of them may prove to be a real milestone for the ICTY. The procedural and evidentiary issues are those that divide judicial bodies and truth commissions. Since the international community has opted to establish a judicial body rather than a truth commission, these questions must be addressed meticulously in a judicial fashion. The musings of the Permanent Court of International Justice (PCIJ) to the effect that an international court "is not bound to attach to matters of form the same degree of importance which they might possess in municipal law"194 should not deter the ICTY from taking procedural and evidentiary issues seriously. The PCIJ's approach is valid only when no substantial prejudice has resulted from such procedural defects. ${ }^{195}$ Moreover, there is much value in making sure that justice not only be fairly done but also be seen fairly done in a criminal tribunal such as the ICTY. The substantive law issue relating to the defense of duress takes on philosophical proportions. It is essentially the question how much we can expect of humanity. Such a question obviously deserves a great deal of soul searching. The tremendous respect that the ICTY commands in world opinion should exert pressure on the ICTY to provide

${ }^{191}$ United States v. Pelullo, 14 F.3d 881, 889-97 (3d Cir. 1994).

${ }^{192}$ Id.

${ }^{193}$ D.P.P. v. Humphrys, 2 All, E.R. 497 (1976).

194 Mavrommatis Palestine Concessions, 1924 P.C.I.J. (ser. A) No. 2, at 34.

${ }^{195}$ Cf. H.W.A. Thirlway, Procedural Law and the International Court of Justice, in FIFTY YEARS OF THE INTERNATIONAL COURT OF JUSTICE 389, 405 (Vaughan Lowe \& Malgoshia Fitzmaurice eds., 1996). 
a proper solution. It is unfortunate that the Trial Chamber has given only questionable answers to these issues. It is hoped that the Appeals Chamber will live up to the great expectations.

Although Erdemovic does not appear to have raised some of the important issues discussed, they should nevertheless be considered by the Appeals Chamber. International tribunals have been observing a tradition that an international tribunal should sua sponte find the applicable law and should never leave the law to the parties, whatever a municipal court might do under such circumstances. As the International Court of Justice stated,

It being the duty of the Court itself to ascertain and apply the relevant law in the given circumstances of the case, the burden of establishing or proving rules of international law cannot be imposed upon any of the Parties, for the law lies within the judicial knowledge of the Court. ${ }^{196}$

Thus, the ICTY has the duty to consider all important arguments, leaving no stone unturned, and to decide what the best remedies would be. This is particularly important when the ICTY is an experiment to do exemplary justice. "As an experiment, it should not be conducted at the expense of the defendant."197

In light of the posture of the case, the procedural irregularities and the substantive law on the defense of duress, the preferred remedy is for the Appeals Chamber to vacate the Sentencing Judgement and remand the case to give Erdemovic a chance to replead. If Erdemovic reaffirms his guilty plea to a crime against humanity and continues to assert his claim of duress, a not guilty plea should be entered. If duress is established, he should not be convicted of a crime against humanity, but may be convicted of an ordinary war crime. In that event, he should be given the benefit of mitigation. If he pleads guilty to an ordinary war crime and asserts his claim of duress, it should be explained to him that duress is no defense to an ordinary war crime, but an issue of mitigation, and he should be asked whether he would still plead guilty. If he does, a guilty plea may be entered and mitigation may be considered.

${ }^{196}$ Fisheries Jurisdiction Case (F.R.G. v. Ice.), 1974 I.C.J. 174, at 181, para. 18.

197 Transcript of Proceedings on May 7, 1996, Prosecutor v. Tadic, No. IT-94-1-T (ICTY, Trial Ch. II), at 35. 
It is true that under Article $25(2)^{198}$ of the ICTY Statute the Appeals Chamber appears to have the power to revise the Trial Chamber's judgment by reducing the conviction of a crime against humanity to that of an ordinary war crime in this case. Although not free from doubt, one may argue that such a power would exist with respect to a conviction after a trial, but not with respect to a conviction resulting from an invalid guilty plea. In the former case, the validity of the conviction is based upon evidential proof pursuant to fair procedure. The Appeals Chamber should perhaps have the power to reduce the conviction of one crime to that of a lesser included crime, if the evidence is sufficient for such a conviction. In the case of a guilty plea, however, the validity of the conviction is primarily based on the plea of the accused and therefore a court should not presume that the accused would also plead guilty to the lesser included charge. Individual will should be respected. Moreover, even if it can be assumed that Erdemovic would plead guilty to the lesser charge, the Appeals Chamber still should remand the case to the Trial Chamber. While it is not completely clear, Erdemovic appears to be entitled to have his sentence for a particular conviction determined by the Trial Chamber in the first instance, which determination may be different from what the Appeals Chamber may make, and which may or may not be appealed to the Appeals Chamber. Since it is possible that Erdemovic may receive a more favorable sentence in the Trial Chamber than in the Appeals Chamber, it would be unfair for the Appeals Chamber to jump ahead of the Trial Chamber to give him a harsher one. In light of the high value we place on liberty, a single day's difference can be said to be prejudicial. Accordingly, the case should be remanded to give Erdemovic a chance to re-plead. ${ }^{199}$

${ }^{198}$ This provision states that "The Appeals Chamber may affirm, reverse or revise the decisions taken by the Trial Chambers."

${ }^{199}$ A reasonable disposition may be to rule that Erdemovic must be presumed to have pleaded guilty to an ordinary war crime for the reason that no rational person would have opted to plead guilty to the more serious charge of a crime against humanity and to remand the case for the sole purpose of determining the penalty, which should be more lenient than the existing one. This approach, however, would deprive the prosecution of the right, if it has not been abandoned, to pursue the more serious charge, see supra note 74 and accompanying text. 
